\title{
Chromian spinels from the Magura Unit (Western Carpathians, Eastern Slovakia) - their petrogenetic and palaeogeographic implications
}

\author{
Katarína BÓNOVÁ ${ }^{1, *}$, Ján SPIŠIAK², Ján BÓNA ${ }^{3}$ and Martin KOVÁČIK ${ }^{4}$ \\ 1 Pavol Jozef Šafárik University in Košice, Institute of Geography, Faculty of Science, Jesenná 5, 04001 Košice, \\ Slovak Republic \\ 2 Matej Bel University, Department of Geography and Geology, Faculty of Natural Sciences, Tajovského 40, 97401 \\ Banská Bystrica, Slovak Republic \\ 3 Kpt. Jaroša 13, 04022 Košice, Slovak Republic \\ 4 State Geological Institute of Dionýz Štúr, Regional centre - Košice, Jesenského 8, 04001 Košice, Slovak Republic
}

Bónová, K., Spišiak, J., Bóna, J., Kováčik, M., 2017. Chromian spinels from the Magura Unit (Western Carpathians, Eastern Slovakia) - their petrogenetic and palaeogeographic implications. Geological Quarterly, 61 (1): 3-18, doi: 10.7306/gq.1292

\begin{abstract}
Detrital chromian spinels in sedimentary rocks provide much information concerning the tectonics of their parental ultrabasic rocks. Chromian spinels occurring in the Eocene to Oligocene deposits from the Magura Nappe were examined to provide some constraints on the history of the Magura Basin. The Magura Nappe is a part of the Flysch Belt belonging to the External Western Carpathians. The Magura Nappe is separated by a narrow zone associated with the Pieniny Klippen Belt and is divided into three principal tectono-lithofacies units (from the $S$ to $N$ ): the Krynica, Bystrica and Rača units. Cr-spinel is a common accessory mineral (2.3-5.9 vol\% of heavy mineral spectra) in the siliciclastic rocks of the Rača and Krynica units. In terms of texture and chemical composition, two types of $\mathrm{Cr}$-spinels were recognized: unaltered and altered. Unaltered spinels were found to contain silicate inclusions such as chromio-pargasite, enstatite, diopside, pargasite, plagioclase and olivine (forsterite). The chromian spinels show wide variations in compositional parameters such as $\mathrm{Cr} \#(0.3-0.7), \mathrm{Mg \#}$ (0.3-0.7), $\mathrm{TiO}_{2}\left(<0.03-1.9\right.$ wt. \%) and $\mathrm{Fe}^{2+} / \mathrm{Fe}^{3+}(2.5-13)$ whereas the differences between the Rača and Krynica units are insignificant. These parameters suggest a peridotitic and volcanic origin of the spinels, respectively. The ophiolite source consisting of harzburgitic mantle peridotites was developed mainly in a supra-subduction zone setting; volcanic spinels indicate an origin in mid-ocean ridge basalts, back-arc basin basalts and sporadically in ocean-island basalts. Concerning their geochemical features, we propose that during the Eocene to Early Oligocene, the ophiolitic detritus in the eastern part of the Magura Basin deposits may have been derived from a source area located in the Fore-Marmarosh Suture Zone (Eastern Carpathians) that is considered an equivalent of the Black Flysch and Ceahlau units. Some Cr-spinels found in the Eocene sedimentary successions may have resedimented from older Late Cretaceous-Paleocene formations of the Magura Unit, which are considered as reworked sedimentary material from the Pieniny Klippen Belt.
\end{abstract}

Key words: Western Carpathians, Magura Basin, provenance, detrital chromian spinel, geochemistry.

\section{INTRODUCTION}

Chromian spinels belong to a group of resistant minerals that often occur as a component of the heavy mineral fraction of sedimentary rocks. In the case of sedimentary rocks, the composition of unaltered $\mathrm{Cr}$-spinels may provide useful petrogenetic information about their source rocks.

Recently, attention has been paid to the Cr-spinels in different rock types of the Western Carpathians. They have been geochemically investigated in metaultramafic rocks from the Tatric crystalline basement (Spišiak et al., 1988, 1998), in

\section{* Corresponding author, e-mail: katarina.bonova@upjs.sk}

Received: February 3, 2016; accepted: March 23, 2016; first published online: April 29, 2016 metaultrabasites from the East Slovakian Basin basement (Iňačovce-Krichevo Unit; Spišiak et al., 2000, 2001), and in Mesozoic ultramafic bodies of the Meliata Unit (Mikuš and Spišiak, 2007). Cr-spinels have also been recognized in sedimentary rocks from the Pieniny Klippen Belt (PKB; Starobová, 1962; Mišík et al., 1980, 1991a; Jablonský et al., 2001; Aubrecht et al., 2009), and in the Poruba flysch Formation located in the Tatric and Fatric (Krížna Nappe) units (Mikuš et al., 2006) and in deposits from the Šambron flysch Zone (Central Carpathian Paleogene basin; Spišiak et al., 2001; Lenaz et al., 2009) and the Gosau Group (Mikuš et al., 2006; Stern and Wagreich, 2013). The chemical composition of $\mathrm{Cr}$-spinels from various sedimentary rock units and stratigraphic levels of the Western Carpathians was investigated by Jablonský et al. (2001), who also provided an overview of the Cr-spinel occurrences in the Western Carpathian Mesozoic sedimentary rocks. The chemical composition of detrital Cr-spinels in the heavy mineral fraction from recent river sediments in the Nízke Tatry Mts. (Tatricum Unit) was examined by Stankovič et al. (2001), while 
study of ultrabasic (metaultrabasic) rocks of the Western Carpathians was made by Hovorka et al. (1985).

Preliminary geochemical data obtained from detrital chromian spinels from the Middle-Late Eocene Magura Fm. sandstones (Krynica Unit, Polish Western Carpathians) suggest that Cr-spinels were supplied only from ophiolites with harzburgitic affinity (Vardar Zone sub-province; Lenaz et al., 2001). The chemical composition of Cr-spinels from the Krynica Unit and from the PKB was studied by Oszczypko and Salata (2005). They proposed that the grains represent a mixture of spinels originating from different parts of the obduced ophiolite.

Cr-spinels were described from the Paleocene to Eocene deposits which crop out in the Eastern Slovakian part of the Flysch Belt (Magura Nappe) by Starobová (1962). Križáni (1985) confirmed their presence in recent alluvial deposits on the Magura Nappe. He proposed that the Cr-spinels represent the "mineralogical record of sources from the Inner Carpathian provenance". Cr-spinels were also found within Orbitolinae limestones (with clasts of basic volcanic rocks) that form part of the turbidite sandstone succession of the Strihovce Fm. (Krynica Unit; Mišík et al., 1991b). They have been identified in the Magura Nappe deposits of Poland (Winkler and Ślączka, 1992, 1994).

This study describes the chemistry of detrital Cr-spinels from the Magura Nappe flysch sandstones and from recent alluvial deposits in Eastern Slovakia. Back-scattered electron (BSE) images and electron microprobe analyses have shown that these Cr-spinels are altered to various degrees, which provide a good opportunity to assess their textural and compositional variations associated with serpentinisation and/or metamorphism. Additionally, the unaltered spinel grains are used as a petrogenetic indicator of their source rocks. Consequently, new geochemical data of $\mathrm{Cr}$-spinels found in Eocene (to Oligocene) flysch deposits from the eastern part of the Magura Nappe are compared with those of the PKB and other successions containing Cr-spinels from the different Western Carpathian units (Meliata and Iňačovce-Krichevo units, Šambron flysch Zone) and from the Polish flysch Western Carpathians with evaluation of their potential sources.

\section{GEOLOGICAL SETTING}

The Magura Nappe - the innermost tectonic unit of the Flysch Belt (Outer Western Carpathians, OWC) is subdivided into three principal tectono-lithofacies units: from south to north, the Krynica, Bystrica and Rača units. These units consist of deep-sea, mostly siliciclastic deposits of Late Cretaceous to Oligocene age (see Fig. 2). In the south, the Magura Nappe is tectonically bounded by the PKB, while in the north-east it is in tectonic contact with the Dukla Unit belonging to the Fore-Magura group of nappes. The Grybów Unit, as the innermost unit of the Fore-Magura group of nappes, crops out in the Smilno tectonic window beneath the Inner Rača Unit (e.g., Lexa et al., 2000).

The Rača Unit represents the northernmost tectono-lithofacies unit of the Magura Nappe in the area investigated. Based on lithofacies differences mainly of the Zlín Formation in its northern and southern parts, two zones are distinguished (Fig. 1; e.g., Kováčik et al., 2011, 2012): the Outer Rača Unit (Siary Unit in the Polish OWC) and the Inner Rača Unit (Rača Unit s.s. in the Polish OWC). These zones are separated by the Krivá Ol'ka overthrust line, generally of NW-SE trend (Menčík and Pesl, 1959; Matějka et al., 1964; Žec et al., 2011; Kováčik et al., 2012).
The Outer Rača Unit crops out north of the Krivá Ol'ka line and consists of the Beloveža and Zlín formations. The Beloveža Formation (Lower Eocene-Midle Eocene) is formed of two facies: thin-bedded flysch and variegated claystones. The Zlín Formation (Middle Eocene-Early Oligocene) forms the prevailing part of the unit. In general, the lower part of the formation is composed of a glauconite-sandstone facies, whereas the upper part is usually formed of a claystone facies with thinner interbeds of glauconite-sandstone facies and brown silicified claystones and siltstones. Dark calcareous claystones in association with the claystone facies are locally present in the uppermost part of the Zlín Fm. The total thickness of the formation reaches $2500 \mathrm{~m}$.

The Inner Rača Unit crops out south of the Krivá Ol'ka line between the Outer Rača Unit in the north-east and the Bystrica Unit in the south-west. It has a wider stratigraphic range, covers a considerably larger area and in comparison with the Outer Rača Unit it has more varied facies content. From its base upwards it is built of the following formations: the Kurimka Fm. (sensu Samuel, 1990), and the Beloveža, Zlín and Malcov fms. (Kováčik et al., 2011, 2012). The Kurimka Formation (Upper Cretaceous-Lower Eocene) crops out south of the Smilno tectonic window. The nature of the underlying rock is not known, but upwards it gradually passes into the Beloveža Formation. The formation is divided into flysch facies (thin- to medium-bedded green and grey claystones with interbeds of quartzose to quartzose-carbonate sandstone) and sandstone facies (quartzose-greywacke sandstones, locally with glauconite). The thickness of the Kurimka Fm. is estimated at 500-800 m. The Beloveža Formation (Paleocene-Middle Eocene) crops out in the frontal parts of particular slices (or in cores of anticlinal structures) of the Inner Rača Unit. The lower part of the formation is formed of the Mrázovce Member, whereas the upper part comprises thin-bedded flysch with the intercalations of variegated claystone. The thickness of the Beloveža Fm. commonly is $200-250 \mathrm{~m}$, up to a maximum of $2000 \mathrm{~m}$ in the Zborov anticlinorium (Nemčok et al., 1990). The Beloveža $\mathrm{Fm}$. is overlain by the Zlín Fm. with a gradational contact. The Zlín Formation (Middle Eocene-Lower Oligocene) of the Inner Rača Unit covers an extensive part of the territory studied and its total thickness reaches $2000 \mathrm{~m}$. The formation is composed of several facies (or lower lithostratigraphic units): the Makovica Sandstones with local layers of conglomerate, a glauconite-sandstone facies (quartzose, arkosic and glauconitic sandstones with olive-green calcareous claystones to siltstones), coarse-grained sandstones and conglomerates (commonly with glauconite), a claystone facies (olive-green calcareous "Zlín-type" claystones and siltstones with glauconitic sandstones) and dark grey and olive-green calcareous claystones with quartzose-carbonate and glauconitic sandstones. The transition into the overlying Malcov Formation is gradual at numerous places and a common occurrence of the Malcov and Zlín lithotypes is expressed by a Zlín-Malcov facies (calcareous claystones, quartzose-carbonate and glauconitic sandstones). The Malcov Formation (Upper Eocene-?Upper Oligocene) reaches a thickness of $1200 \mathrm{~m}$ and its bed succession dominates the flysch facies (grey calcareous "Malcov-type" claystones to siltstones with interbeds of quartzose-carbonate sandstone). Within this formation several smaller lithostratigraphic units (or facies) of considerable stratigraphic importance have been distinguished. The lower part of the Malcov Fm. is built of thin interbeds of laminated Tylawa limestones and Globigerina Marlstones in close contact with variegated (mostly red-brown) claystones and the Menilite Member. In the upper parts of the formation the younger horizons of the Menilite Member occur.

The Bystrica Unit is overthrusted on the Inner Rača Unit on the northeastern side and in the south it is in tectonic contact 


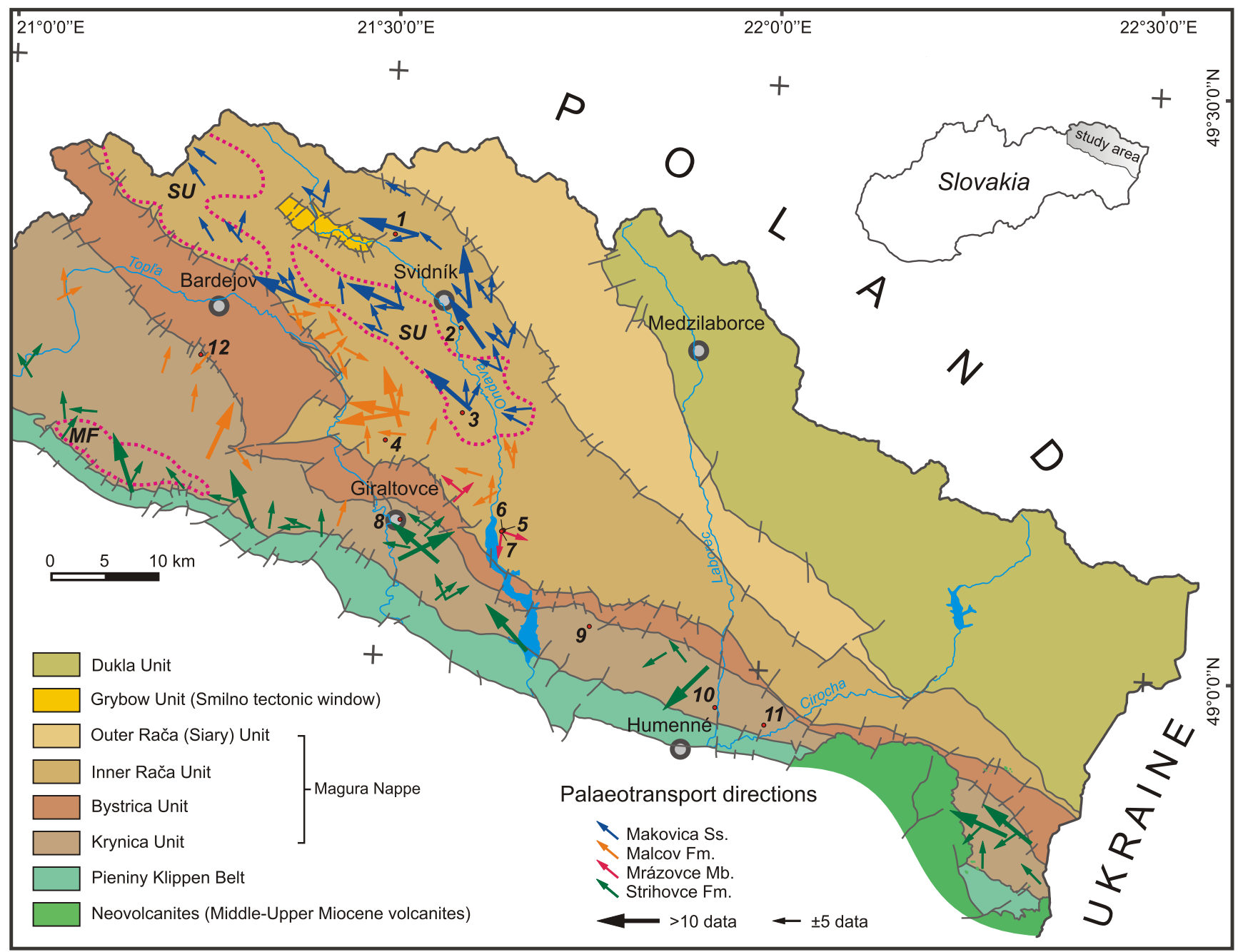

Fig. 1. Simplified and partly modified structural sketch map of the NE part of the Slovak Outer Western Carpathians (according to Stránik, 1965; Koráb, 1983; Nemčok, 1990; Žec et al., 2006; Kováčik et al., 2011; Geological map of Slovakia at 1:50,000 scale [online], 2013 - taken from Bónová et al., 2016, modified) with sampling points (1-12)

Fields with purple dotted lines show the sampling points of panned concentrates (SU, MF samples); palaeotransport directions are shown according to Koráb et al. (1962), Stránik (1965), Nemčok (1990), Kováčik et al. (2009, 2012), Žec et al. (2011), Bónová et al. (2016); sampling: 1 - BZK-318, 2 - BZK-700, 3 - BZK-264, 4 - BZK-322a, 5 - MRA-1, 6 - MRA-2, 7 - MRA-4, 8 - GIR-1, 9 - KOS-1, 10 - UD-1, 11 KNC-4, 12 - BZKo-765

with the Krynica Unit. The oldest lithostratigraphic unit of the Bystrica Unit is the Beloveža Formation (Paleocene-Middle Eocene). The lower part is represented by a sandstone facies (locally with conglomerates). The upper part is formed of thin-bedded flysch locally with interbeds of variegated claystone. The thickness of this formation is estimated at $50-200 \mathrm{~m}$. The Zlín Formation (Middle Eocene-Upper Eocene) is formed mainly of a sandstone facies and claystone facies. In general, the sandstone facies mainly forms the lower part of the formation, whereas the claystone facies is dominant in its upper part.

The Krynica Unit is the southernmost tectono-lithofacies unit of the Magura Nappe and consists of the Proč, Čergov, Strihovce and Malcov formations. The Proč Fm. is commonly regarded as a part of the PKB (e.g., Nemčok, 1990; Lexa et al., 2000). However, subsequent research in the study area showed a facies transition (Jasenovce Mb.) between the Proč and Strihovce fms. and so both formations constitute an integral part of the Krynica Unit (Potfaj in Žec et al., 2006; Žec et al., 2011). The Čergov Formation (Lower Eocene-Middle Eocene) is pres- ent in the Čergov Mts. (Nemčok, 1990) and consists of two basic facies: a sandstone facies (medium to coarse-grained arkosic sandstones) and a thin- to thick-bedded sandstone-claystone facies (Nemčok et al., 1990). The Strihovce Formation (Lower Eocene-Upper Eocene) dominates in the Nízke Beskydy Mts. (cf. Žec et al., 2006; Kováčik et al., 2012) and represents succession of quartzose-greywacke (Strihovce) sandstones several hundred metres thick with intercalations of mostly oligomict conglomerate. Significant facies is represented by polymict conglomerates with pebbles of exotic rocks. Sandy claystones are developed above the polymict conglomerates. The flysch facies locally includes intercalations of variegated claystone.

The Malcov Formation (Upper Eocene-?Upper Oligocene) is the youngest formation of the Krynica Unit in the region studied and its thickness is estimated at 800-1200 m. The flysch facies (grey calcareous claystones and siltstones with layers of quartzose-carbonate sandstone) is the main and the most extended facies of this formation. At several levels a sandstone facies is present, locally with layers of conglomerate. The lower 


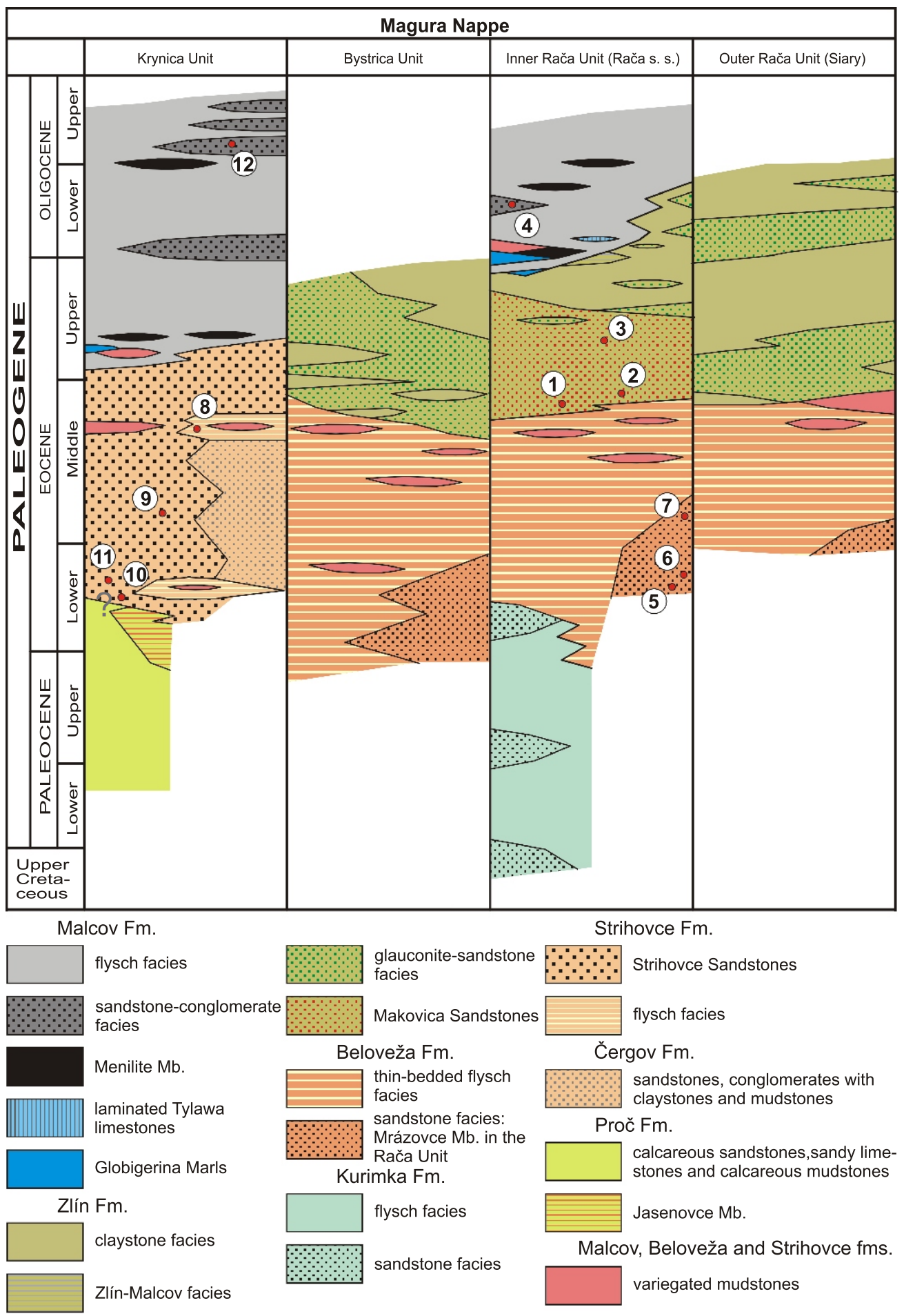

Fig. 2. Lithostratigraphy of the Magura Nappe in the Nízke Beskydy Mts. and adjacent areas (compiled after Nemčok et al., 1990; Potfaj in Žec et al., 1997; Žec et al., 2011 and Kováčik et al., 2012)

Lithology taken from Bónová et al. (2016), modified; sampling points are the same as in Figure 1

part of the Malcov Fm. is sporadically built of variegated claystones and Menilite Member. The Menilite Member is known also from the higher (younger) parts of this formation.

All of these formations contain sandstones carrying heavy minerals such as garnet, tourmaline, zircon, rutile, chromian spinel, apatite, staurolite, glauconite, kyanite and amphibole (except the Makovica Ss.). Rare pyroxene occurs in the Strihovce and Malcov fms. Two grains of titanite were found in the Strihovce Fm., and traces of titanite are also present in the Mrázovce Mb. (Appendix 1*).

\footnotetext{
* Supplementary data associated with this article can be found, in the online version, at doi: $10.7306 / \mathrm{gq} .1292$
} 


\section{PALAEOFLOW DIRECTIONS}

Palaeoflow direction analysis is also of great importance for these provenance studies. We briefly summarize the palaeoflow data of the units and formations from which the samples have been studied (Fig. 1).

The inner and older part of the Magura Basin is formed of relatively coarser-grained deposits of the Krynica Unit (Proč, Strihovce and Čergov formations). Sedimentary gravity flows brought clastic material mostly from the S, SE and E to the N NW and W (longitudinal filling, Koráb et al., 1962). Several data point to directions from SW to NE. It was inferred that lateral sediment input turned to flow along the axis of the basin (Koráb et al., 1962). The younger Malcov Fm. has a much more varied palaeoflow record indicating contribution of sedimentary material from several directions. As well as the dominant flow direction from SE to NW there was also a significant input of clastic sediment from peripheral parts - generally from the SW to NE and from the NE to SW (Bónová et al., 2016).

The middle and outer (northern) part of the Magura Basin is mostly represented by the Rača Unit. The lowermost part of the Beloveža Fm. in the Inner Rača Unit (Mrázovce Member, sensu Kováčik et al., 2012) has the character of an upward-fining and upward-thinning flysch succession (channel-levee complex) with palaeoflow direction mainly from NW to SE (Kováčik and Bóna, 2005). The Makovica Sandstones Member represents a significant part of the Zlín Fm. in the Inner Rača Unit and its palaeoflow record has been relatively well-studied (Koráb et al., 1962; Nemčok and Koráb, 1963; Kováčik et al., 2009). The Makovica Sandstones Member is a "turbidity system" characterized by lithofacies change along the flow direction of gravity currents. The main direction of the flows was from SE to NW, though with some differences in the various parts of the system. The SE part of the system shows a palaeoflow direction from SE to NW or NNW with local variations to the $\mathrm{N}$ and NE. In the NE part the dominant flow direction is from ESE to WNW with dispersion to the NW and W (Kováčik et al., 2009). Data from the Zlín Fm. of the Outer Rača Unit indicate similar palaeoflow directions as those in the Inner Rača Unit - longitudinal filling generally from the SE to NW. Some differences have been observed near the northern border of the unit, where directions from the NE to SW and NW to SE have been recorded (Koráb et al., 1962; our observations).

\section{MATERIAL AND METHODS}

12 samples were collected from 10 localities (Fig. 1). For the Rača Unit, the sampled material includes the Beloveža (Mrázovce Member: 3 samples), Zlín (Makovica Sandstones: 3 samples) and Malcov (1 sample) formations. For the Krynica Unit, 4 samples were taken from the Strihovce Fm. and 1 sample from the Malcov Fm.

Sandstone samples weighing $5-10 \mathrm{~kg}$ were collected for the preparation of heavy mineral concentrates. Heavy mineral concentrates from sandstones were obtained by the standard methods from the 0.025 to $0.063 \mathrm{~mm}$ size fraction with final separation in heavy liquid (tetrabromethane with $\mathrm{D}=$ $2.96 \mathrm{~g} / \mathrm{cm}^{3}$ ). Concentrates were qualitatively and quantitatively evaluated with a focus on the translucent heavy minerals. Totals of 350 to 450 grains were optically evaluated.

For comparison, we included Cr-spinel analyses from recent alluvial deposits in the Magura Nappe (Fig. 1). Panned concentrates were taken by standard panning of 5-10 cubic decimetres of the sandyclay fraction. The average sampling density corresponds to a scale of 1:50,000. For geochemical analysis, we used $\mathrm{Cr}$-spinels from two areas: the Peri-Klippen zone of the Magura Unit (MF sample) and the Inner Rača Unit (SU sample). Spinels were selected to cover the entire shape and colour spectra. The distribution Cr-spinels from the panned concentrates is shown on the map (Fig. 1).

$\mathrm{Cr}$-spinels were picked by hand and analysed in polished thin-sections using an electron microanalyser Cameca SX 100 (State Geological Institute of Dionýz Štúr, Bratislava, Slovak Republic) with the WDS method at accelerating voltages of $15 \mathrm{kV}$, a beam current of $20 \mathrm{nA}$ and an electron beam diameter of $5 \mu \mathrm{m}$. To measure concentrations of various elements the following natural and synthetic standards were used: orthoclase $(\mathrm{Si} \mathrm{K} \alpha), \mathrm{TiO}_{2}(\mathrm{Ti} \mathrm{K} \alpha), \mathrm{Al}_{2} \mathrm{O}_{3}(\mathrm{Al} \mathrm{K} \alpha), \mathrm{Cr}(\mathrm{Cr} \mathrm{K} \alpha)$, fayalite $(\mathrm{Fe} \mathrm{K} \alpha)$, rhodonite $(\mathrm{Mn} \mathrm{K} \alpha)$, forsterite $(\mathrm{Mg} \mathrm{K} \alpha)$, wollastonite $(\mathrm{Ca} \mathrm{K} \alpha)$, Ni $(\mathrm{Ni} \mathrm{K} \alpha)$, willemite $(\mathrm{Zn} \mathrm{K} \alpha)$ and $\mathrm{V}_{2} \mathrm{O}_{5}(\mathrm{~V} \mathrm{~K} \alpha)$.

For the Rača Unit, chemical data of 18 detrital spinels were taken from the MRA-1, MRA-2, MRA-4 samples of the Mrázovce Mb. (Mrázovce village); from the BZK-700 sample (Svidník - Kaštielik Quarry; 13 analysed grains), the BZK-318 sample (Vyšný Orlík Quarry; 12 analysed grains) and the BZK-264 sample (Baňa Quarry; 14 analysed grains) - all from the Makovica Sandstones (Zlín Fm.), and from the BZK-322a sample (Štefurov locality; 5 analysed grains) of the Malcov Fm.

For the Krynica Unit, Cr-spinels were analysed from the KNC-4 sample (Kamenica n/Cirochou Quarry; 14 analysed grains), from the KOS-1 sample (Košarovce Quarry; 8 analysed grains), from the UD-1 sample (Udavské locality; 9 analysed grains) and from the GIR-1 sample (Giraltovce locality; 13 analysed grains) of the Strihovce Fm., and from the BZKo-765 sample (Kl'ušov locality; 9 analysed grains) of the Malcov Fm.

Two analyses of each grain were made, one in the centre (grain core) and the other near the rim, away from microveins. Analyses of grains were calculated on the basis of 3 cations. $\mathrm{Fe}^{2+}$ and $\mathrm{Fe}^{3+}$ in spinel were allocated according to the ideal stoichiometry. Back-scattered electron image (BSE) observations were carried out using the same instrument.

For classification of amphibole inclusions Hawthorne's et al. (2012) classification scheme was used (chemical formulae were calculated sensu Locock, 2014). Pyroxene inclusions were classified according to Morimoto et al. (1988).

\section{RESULTS}

\section{OCCURRENCE OF CHROMIAN SPINELS}

The amount of detrital chromian spinel in heavy mineral spectra in the siliciclastic rocks from the Magura Nappe is variable: up to 5.9 vol\% in the Krynica and up to 2.3 vol\% in the Rača units, respectively (Appendix 1). Spinel grains usually exhibit subhedral to euhedral shapes (Fig. 3A, B, K). Fragments (angular shapes) and rounded grains indicating a recycled origin also occur. Spinel long diameter ranges from 60 to $150 \mu \mathrm{m}$. From the textural point of view, two different occurrences of Cr-spinels were found in siliciclastic rocks of both units - unaltered and altered. Some grains are visibly zoned. The inclusions are also present (Fig. 3B-E).

\section{CHEMISTRY OF CHROMIAN SPINELS}

Representative chemical compositions of the detrital chromian spinels are shown in Appendix 2. According to their chemical compositions, Cr-spinels can be divided into the low-Ti 

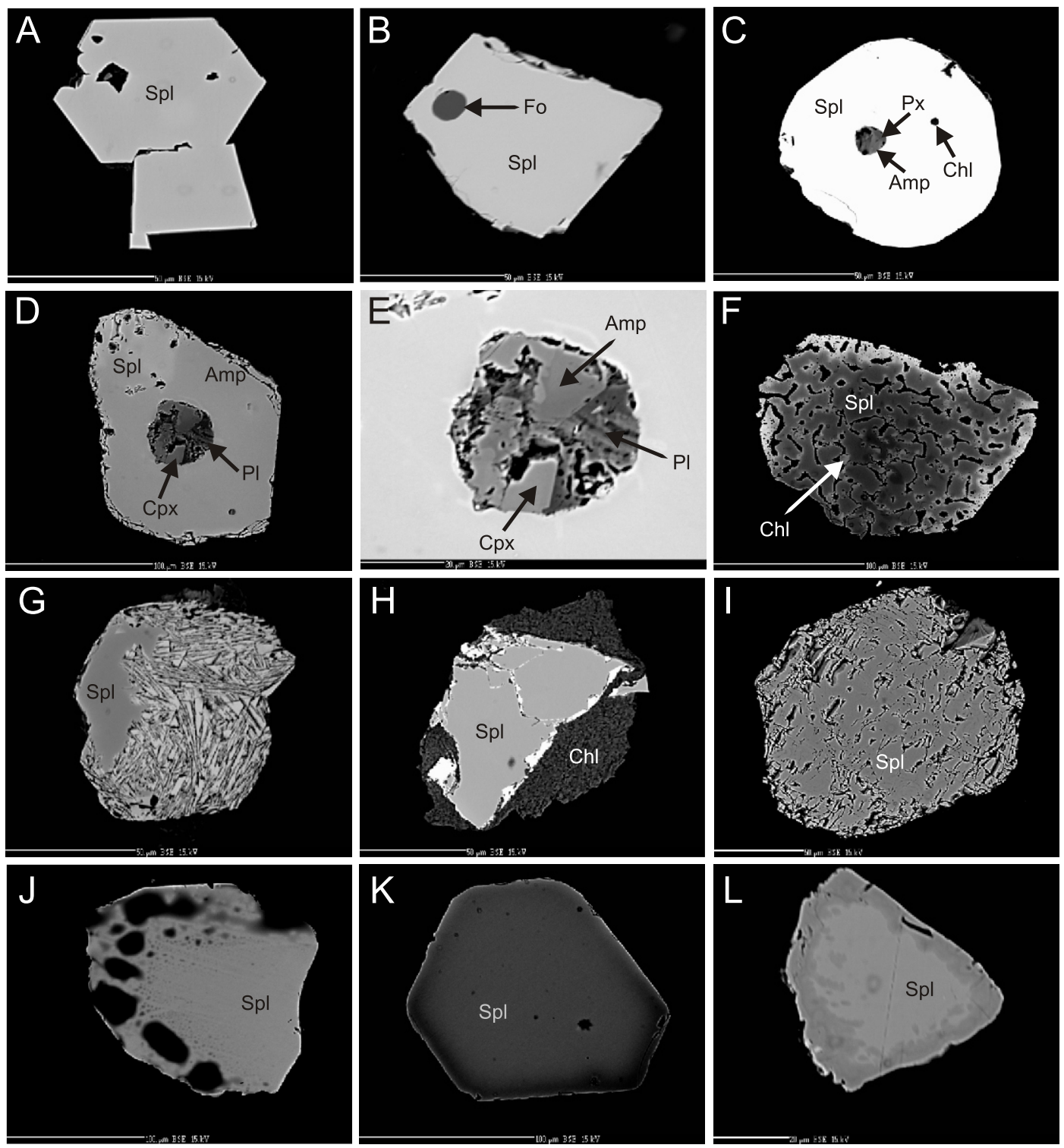

Fig. 3. Back-scattered electron (BSE) images of Cr-spinels from the Magura Basin deposits

A - euhedral shape of an unzoned homogeneous Cr-spinel (MRA-4 sample); B - forsterite inclusion in unzoned magnesiochromite (BZK-700 sample); C - chromio-pargasite coupled with an enstatite inclusion in chromite (BZK-264 sample); D - inclusion of pargasite, diopside and plagioclase intergrowths in magnesiochromite (GIR-1 sample); E - D photo in detail; F - Cr-spinel with porous "myrmekitic" structure; the pores are filled with secondary chlorite (BZK-264 sample); G - massive alteration of Cr-spinel to ferritchromite (BZK-318 sample); H - zoned Cr-spinel consists of a dark grey magnesiochromite core followed by an irregular ferritchromite zone showing a light grey colour and Cr-chlorite surroundings (BZK-264 sample); I - chromite shows signs of decomposition its heterogeneous structure (KNC-4 sample); $\mathbf{J}-\mathrm{Cr}$-spinel shows a porous structure forming a sieve texture; the pores towards the outer grain boundary form round bubbles (KNC-4 sample); $\mathbf{K}$ - euhedral Cr-spinel with altered zone along its margin; $\mathrm{L}$ - up-grade alteration of $\mathrm{Cr}$-spinel toward to its core (MRA-4 sample); Fo - forsterite, Apm - amphibole, Px, CPx - pyroxene, PI - plagioclase, Chl - chlorite, Spl - spinel

$\left(\mathrm{TiO}_{2}<0.2\right.$ wt. $\left.\%\right)$ and high-Ti $\left(\mathrm{TiO}_{2}>0.2\right.$ wt. $\left.\%\right)$ groups. Under the binocular microscope, both high- $\mathrm{TiO}_{2}$ and low- $\mathrm{TiO}_{2}$ spinels are black.

According to Stevens's (1944) classification, which is based on $\mathrm{Cr}, \mathrm{Al}$ and $\mathrm{Fe}^{3+}$ contents, spinels are represented by aluminium-chromite, chromian-spinel and ferritchromite (altered spinels). The parameters $\mathrm{Cr} \#, \mathrm{Mg} \#$ and $\mathrm{Fe}^{3+} \#$, which are defined as $\mathrm{Cr} /(\mathrm{Cr}+\mathrm{Al}), \mathrm{Mg} /\left(\mathrm{Mg}+\mathrm{Fe}^{2+}\right)$, and $\mathrm{Fe}^{3+} /\left(\mathrm{Cr}+\mathrm{Al}+\mathrm{Fe}^{3+}\right)$, respectively, classify them as chromite and magnesiochromite, more rarely spinel s.s. (Deer et al., 1992). Alterations shift the spinel composition closer to chromite. Alteration usually occurs along the entire profile of the grains analysed.

Pearson's correlation coefficient $(r)$ was used to check if any correlation exists between different cations in Cr-spinels (Appendix 3). This index is a measure of the linear correlation between two variables, giving a value between +1 and -1 , where 1 
is a total positive correlation (an increase in one variable is accompanied by an increase in the second one), 0 is no correlation, and -1 is total negative correlation (an increase in one variable is accompanied by an decrease in the second one). Figure 4 shows the strong negative correlations of $\mathrm{Cr}^{3+}$ (a.p.f.u.) with $\mathrm{Al}^{3+}$ ( $r$ value ranges from -0.73 to -0.98 ) and $\mathrm{Mg}^{2+}$ with $\mathrm{Fe}^{2+}(r=-1)$ for all formations (Appendix 3$)$. The most important compositional variations in $\mathrm{Cr}$-spinels follow the influence of tetrahedral $\mathrm{Fe}^{2+} \leftrightarrow \mathrm{Mg}^{2+}$ and octahedral $\mathrm{Al}^{3+} \leftrightarrow \mathrm{Cr}^{3+}$ substitutions. There is usually moderate negative correlation of $\mathrm{Cr}^{3+}$ with other elements $\left(\mathrm{Mg}, \mathrm{Fe}^{3+}\right)$ in the bulk samples investigated from all formations (except for the SU sample, where there is no correlation between $\mathrm{Cr}^{3+}$ and $\left.\mathrm{Fe}^{3+}\right)$. A few altered grains show a more pronounced negative correlation between $\mathrm{Cr}^{3+}$ and $\mathrm{Fe}^{3+}$. This peculiarity is apparent in samples from the Mrázovce Member (Beloveža Fm., Rača Unit) and from the Malcov Fm. A negative correlation with a higher dispersal of analysed points between $\mathrm{Cr}$ and $\mathrm{Ti}$ is also obvious (Fig. 4A).
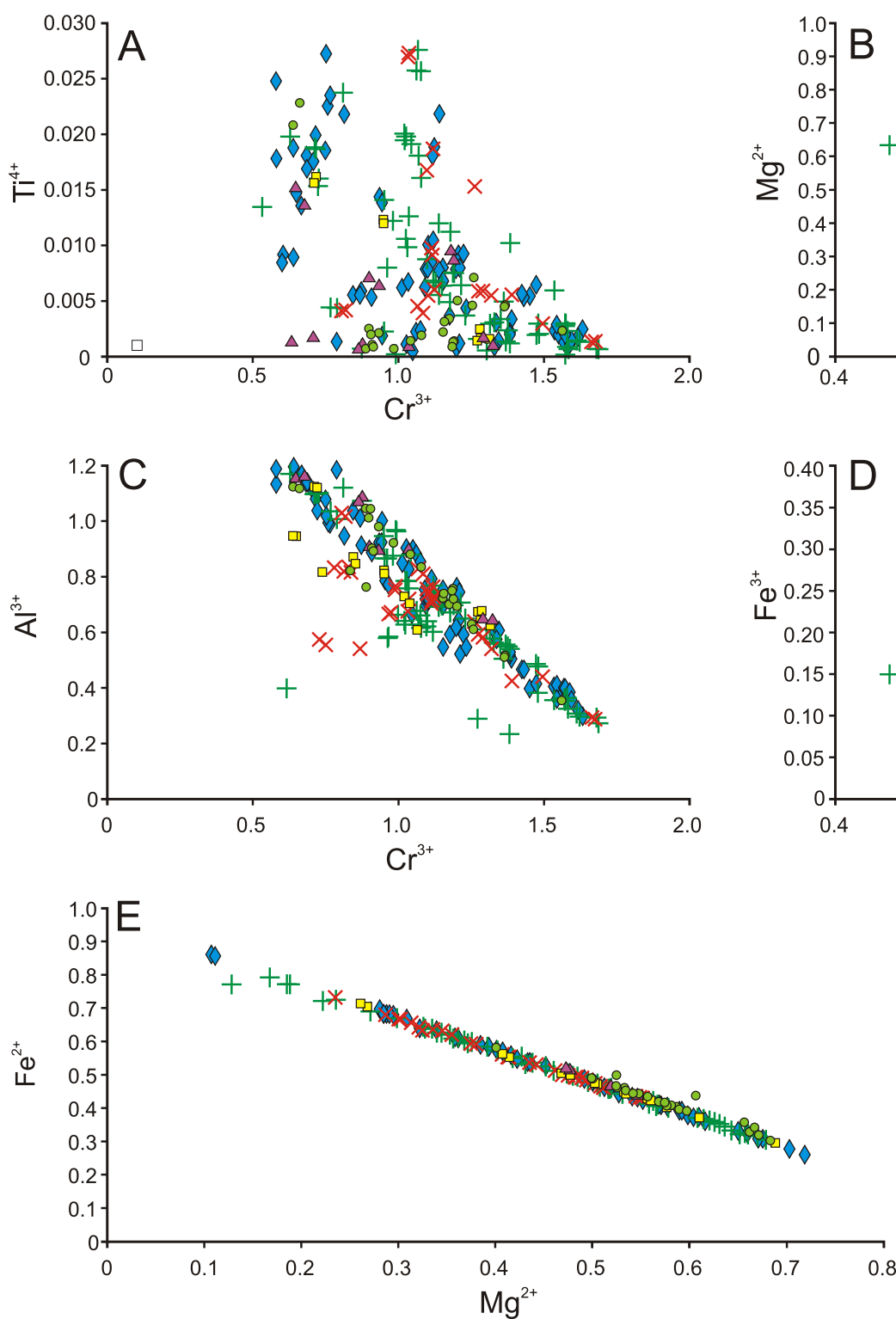

Fig. 4. Correlation diagrams between main chemical elements (a.p.f.u.) in $\mathrm{Cr}$-spinels $\mathrm{A}-\mathrm{Cr}^{3+}$ vs. $\mathrm{Ti}^{4+}, \mathrm{B}-\mathrm{Cr}^{3+}$ vs. $\mathrm{Mg}^{2+}, \mathrm{C}-\mathrm{Cr}^{3+}$ vs. $\mathrm{Al}^{3+}, \mathrm{D}-\mathrm{Cr}^{3+}$ vs. $\mathrm{Fe}^{3+}, \mathrm{E}-\mathrm{Mg}^{2+}$ vs. $\mathrm{Fe}^{2+}$
Rača Unit. Chromian spinels demonstrate a wide compositional range. Unaltered high-Ti grains are generally primary phase, optically and chemically homogeneous, with $\mathrm{Cr} \#$ from 0.4 to 0.68 and $\mathrm{Mg \#}$ from 0.3 to 0.69 (Appendix 2). Generally, $\mathrm{TiO}_{2}$ content is high at intervals from 0.2 to 1.08 wt. $\%, \mathrm{Al}_{2} \mathrm{O}_{3}$ is between 17 and $32 \mathrm{wt} . \%$ and $\mathrm{Fe}^{2+} / \mathrm{Fe}^{3+}$ ratio ranges between 1.8 and 8.6. The $\mathrm{Cr} \#$ of low- $\mathrm{Ti}$ spinels $\left(\mathrm{TiO}_{2}\right.$ is around $\left.0.1 \mathrm{wt} . \%\right)$ ranges from 0.45 to 0.7 and the $\mathrm{Mg \#}$ varies from 0.37 to 0.7 . The $\mathrm{Fe}^{2+} / \mathrm{Fe}^{3+}$ ratio ranges between 2.9 and 9.8 and the $\mathrm{Al}_{2} \mathrm{O}_{3}$ content is from 15 to 32 wt.\%. We observed a higher Al content (50.1 wt.\% $\mathrm{Al}_{2} \mathrm{O}_{3}$ ) in one sample from recent alluvial deposits (SU sample). $\mathrm{Zn}$ content in the $\mathrm{Cr}$-spinels varies from 0.02 to 0.34 wt. $\% \mathrm{ZnO}$.

Altered chromian spinels show heterogeneous textures (Fig. 3F-L). Altered zones have formed along the margins (Fig. $3 \mathrm{~K}, \mathrm{~L}$ ), less along the cracks of Cr-spinel grains. Alteration along the rims and fractures shows depletion of $\mathrm{Cr}, \mathrm{Al}$, and $\mathrm{Mg}$ and enrichment in $\mathrm{Fe}$ as major elements and for minor ele-
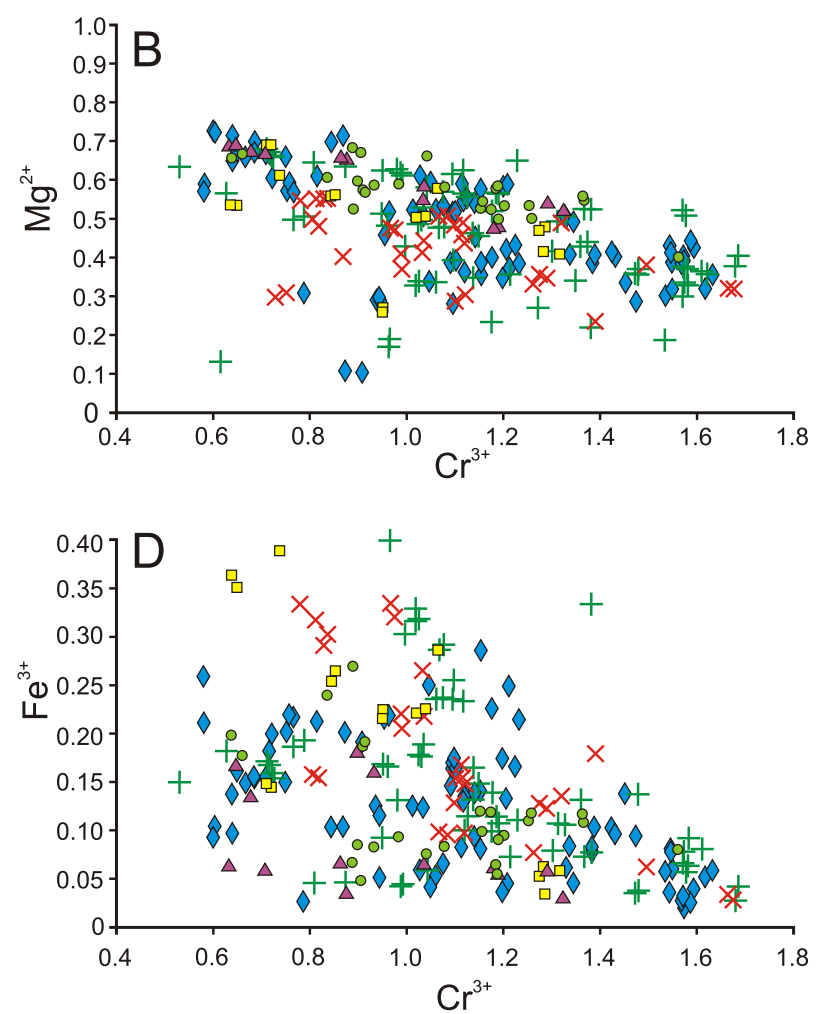

× Mrázovce Mb

+ Makovica Ss.

$\diamond$ Strihovce Fm.

口 Malcov Fm.

- MF

$\triangle \mathrm{SU}$ 
ments there was enrichment in $\mathrm{Ti}$ and less so in $\mathrm{Mn}, \mathrm{Zn}$ and $\mathrm{Si}$ (Appendix 2). The second group consists of the altered $\mathrm{Cr}$-spinels in which $\mathrm{Cr}_{2} \mathrm{O}_{3}$ content $(\mathrm{Cr} \# \sim 86 \mathrm{~mol} \%)$ markedly increases at the expense of $\mathrm{Al}_{2} \mathrm{O}_{3}$, while the content of $\mathrm{TiO}_{2}$ does not usually change. Alteration types are described below.

According to the diagram used to determine $\mathrm{Cr}$-spinel origin (Lenaz et al., 2000; Kamenetsky et al., 2001), the analyses lie within the field of supra-subduction zone peridotites and volcanic spinels (BABB - back-arc basin basalt and MORB - mid-ocean ridge basalt, rarely OIB - ocean-island basalt), respectively (Fig. 5).

Krynica Unit. Moderate Cr\# ratios of 0.3 to 0.6 and of $\mathrm{Mg \#}$ from 0.4 to 0.74 are characteristic values for the unaltered high-Ti spinel grains. $\mathrm{TiO}_{2}$ content varies at intervals from 0.2 to 1.9 wt. $\%, \mathrm{Al}_{2} \mathrm{O}_{3}$ is between 18 and 39 wt. $\%$ and $\mathrm{Fe}^{2+} / \mathrm{Fe}^{3+}$ ratio ranges between 1.8 and 5.9. On the other hand, the $\mathrm{Cr}$ \# of low-Ti spinels $\left(\mathrm{TiO}_{2}<0.1 \mathrm{wt} . \%\right)$ ranges from 0.5 to 0.6 and the $\mathrm{Mg} \#$ from 0.3 to 0.6 , rarely 0.7 in samples from the recent alluvial deposits (Appendix 2). The $\mathrm{Fe}^{2+} / \mathrm{Fe}^{3+}$ ratio ranges in extended intervals between 2.5 and $13 . \mathrm{Al}_{2} \mathrm{O}_{3}$ content is between 13 to 32 wt. \%.

Altered spinels (e.g., UD -1 sample) are characterized by an increase in $\mathrm{Fe}$ and $\mathrm{Cr}$. They are depleted in $\mathrm{Al}$ and $\mathrm{Mg}$. Additional features of some altered spinels are minimal changes in $\mathrm{FeO}$ content (i.e. $\mathrm{Fe}_{2} \mathrm{O}_{3}$ is negligible) but significant gain of $\mathrm{Cr}_{2} \mathrm{O}_{3}$ content ( $\mathrm{Cr}$ up to $83 \mathrm{~mol} \%$ ) at the expense of $\mathrm{Al}_{2} \mathrm{O}_{3}$.

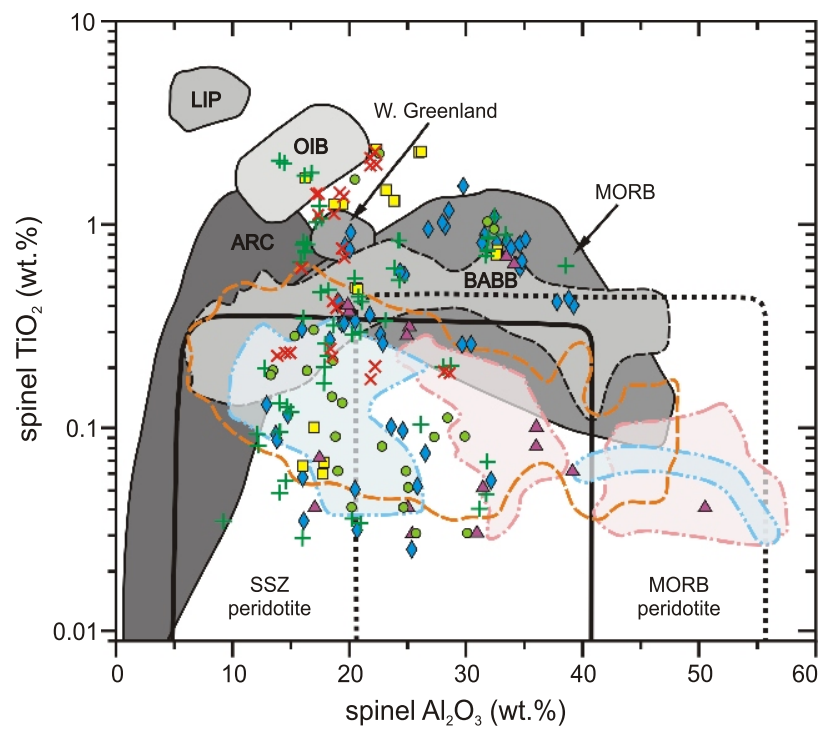

Fig. 5. Chromian spinel discrimination diagram

$\left(\mathrm{Al}_{2} \mathrm{O}_{3}\right.$ vs. $\left.\mathrm{TiO}_{2}\right)$ showing the composition of $\mathrm{Cr}$-spinels analysed from various Magura flysch units

Compositional fields of spinels are imaged sensu Kamenetsky et al. (2001): LIP - large igneous provinces, OIB - ocean-island basalt, MORB - mid-ocean ridge basalt, ARC - island-arc basalt, SSZ - peridotite of supra-subduction zone, MOR - peridotite; BABB - back-arc basin basalt (sensu Lenaz et al., 2000); Cr-spinels from the Meliata Unit (light pink fields with dot-and-dash lines; Mikuš and Spišiak, 2007), from the Czorsztyn Unit (light blue fields with double dot-and-dash lines; Aubrecht et al., 2009) and from the Jarmuta and Szczawnica formations (PKB and Krynica Unit, respectively; colourless field with orange dashed line; Oszczypko and Salata, 2005) are plotted for comparison; explanations as for Figure 4
This phenomenon is reflected by high values of the $\mathrm{Fe}^{2+} / \mathrm{Fe}^{3+}$ ratio (up to 21).

According to the provenance diagram (Lenaz et al., 2000; Kamenetsky et al., 2001), analyses of Cr-spinels lie, as do those of the Rača Unit, within the field of supra-subduction zone peridotites and volcanic spinels of BABB and MOR basalt origin, respectively (Fig. 5).

Malcov Formation (Rača and Krynica units). The chemical composition shows different contents of the main oxides: $\mathrm{Cr}_{2} \mathrm{O}_{3}$ $\left(\sim 50\right.$ wt. \%) dominates in most grains analysed. $\mathrm{Al}_{2} \mathrm{O}_{3}$ content is within the range of 16 to 33 wt. \%. High $\mathrm{TiO}_{2}(0.7-2.3 \mathrm{wt} . \%)$ and low $\left[\mathrm{Fe}^{2+} / \mathrm{Fe}^{3+}=(1.0-2.15)\right]$ ratios suggest a volcanic origin for the bulk of the grains analysed (Lenaz et al., 2000; Kamenetsky et al., 2001), with Mg\# between 0.5 and 0.7. Grains containing $\mathrm{TiO}_{2}$ up to 0.1 wt. $\%, \mathrm{Fe}^{2+} / \mathrm{Fe}^{3+}=(8.9-14.5)$ and $\mathrm{Mg} \#=0.4-0.5$ are also present. The spinels are usually unzoned and homogeneous. Some grains are rich in $\mathrm{TiO}_{2}, \mathrm{Al}_{2} \mathrm{O}_{3}$ and $\mathrm{FeO}$, which increase at the expense of $\mathrm{Cr}_{2} \mathrm{O}_{3}$ towards the grain peripheries. Other grains show higher contents of $\mathrm{MnO}(0.49 \mathrm{wt} . \%)$ and $\mathrm{ZnO}$ $(0.43 \mathrm{wt} . \%)$ and this may indicate alteration, although this is not shown by the texture of the grains. Decrease in $\mathrm{Al}_{2} \mathrm{O}_{3}$ content at the grain peripheries, typical of alteration and/or metamorphic processes (e.g., Burkhard, 1993; Liipo et al., 1994; Power et al., 2000; Mikuš et al., 2006; Mikuš and Spišiak, 2007), does not occur (Bónová et al., 2016). According to the diagram applied to determine Cr-spinel origin (Lenaz et al., 2000; Kamenetsky et al., 2001), the samples investigated lie within the field of supra-subduction zone peridotites and volcanic spinels, respectively. The volcanic spinels fall outside the boundaries of different tectonic settings (Fig. 5).

\section{INCLUSIONS WITHIN CHROMIAN SPINELS}

Inclusions are usually present in fresh Cr-spinel grains that are almost free of alteration (according to BSE images, Fig. $3 B-E)$. Silicate inclusions of amphibole, pyroxene, plagioclase and olivine are trapped in spinels from both tectono-lithofacies units:

1 - A chromian spinel with low $\mathrm{Ti}$ content $(0.13 \mathrm{wt} . \%$ $\mathrm{TiO}_{2}$ ) coexisting with a forsterite $\left(\mathrm{FO}_{94}\right)$ inclusion has a magnesiochromite composition (sensu Deer et al., 1992; BZK-700 sample, Rača Unit, Fig. 3B, see Appendixes 2 and 4 ). There are no cracks around and across the forsterite inclusion. Cr-spinel composition in equilibrium with $\mathrm{Fo}_{94}$ Olivine indicates a relatively low temperature $\left(\sim 760^{\circ} \mathrm{C}\right)$ and sub-solidus re-equilibration (Fe-Mg exchange) between spinel and olivine during cooling in magmatic conditions (cf. Farahat, 2008). The forsterite has a high content of $\mathrm{NiO}(0.5 \mathrm{wt} . \%)$ and its composition corresponds to that of olivine from ultrabasic rocks (Deer et al., 1997). It may have been derived from a nearly primitive magma.

2 - Chromio-pargasite coupled with enstatite (Appendix 4) occurs within chromite in a sample (BZK-264) from the Rača Unit. The chromite shows an unzoned homogeneous texture. It has an almost identical chemical composition from the core to the grain periphery. A chlorite inclusion trapped within the same chromite (Fig. $3 \mathrm{C})$ is enriched in $\mathrm{Mg}\left(\mathrm{MgO}=20.46\right.$ wt. \%) and $\mathrm{Cr}\left(\mathrm{Cr}_{2} \mathrm{O}_{3}\right.$ $=4.32$ wt. $\%$ ) contents.

3 - An inclusion formed by pargasite and diopside (+/-plagioclase) intergrowths appears in an unaltered magnesiochromite (sensu Deer et al., 1992) with very 
low $\mathrm{Ti}\left(0.05\right.$ wt. \% $\left.\mathrm{TiO}_{2}\right)$ from the Krynica Unit (GIR-1 sample, Fig. 3D, E).

The primary silicate inclusions have been altered to chlorite (e.g., BZK-264, KOS-1 samples) in altered chromian spinels.

\section{ALTERATION AND TEXTURE PARTICULARITY OF CR-SPINELS}

The heterogeneous textures of the spinels studied are shown in Figure 3. In the framework of the grains investigated, several types of altered textures have been identified optically and chemically:

1 - Cr-spinel with porous "myrmekitic" structure, where the pores are filled with secondary chlorite (BZK-264 sample, Fig. 3F). The grain exhibits a significant zoning manifested by a decrease in $\mathrm{Al}, \mathrm{Mg}$ and increase in $\mathrm{Ti}, \mathrm{Fe}$ and $\mathrm{Mn}$ towards the rim. Alteration of spinel is expressed more clearly by the $\mathrm{SiO}_{2}$ content (up to $0.7 \mathrm{wt} . \%$ ).

2 - Massive alteration of $\mathrm{Cr}$-spinel to ferritchromite (BZK-318 sample, Fig. 3G).

3 - Optically zoned Cr-spinel consists of a dark grey magnesiochromite core followed by an irregular pale grey ferritchromite zone. The slightly brighter edges of this grain in BSE images result from an increase in its $\mathrm{Fe}^{2+}$ content and a decrease in $\mathrm{Mg}^{2+}$. The ferrian chromite rim is not accompanied by development of $\mathrm{Cr}$-magnetite at its margin. However, peripheral development of $\mathrm{Cr}$-chlorite aureoles is common (Fig. $3 \mathrm{H}$ ). The inner parts of the grains are usually not modified by secondary processes. This phenomenon was observed mainly in Cr-spinels from the Rača Unit (Makovica Ss., BZK-264, BZK-318 samples).

4 - In sample KNC-4 (Krynica Unit), chromite with signs of the decomposition of its heterogeneous structure is characteristic. The chemical composition of the grain is the same along the whole profile (Fig. 3I).

5 - Within the Krynica Unit samples (Kamenica and Košarovce localities), Cr-spinels were identified showing a porous structure. The pores are not associated with fractures within the host spinel. The pores are located either concentrically, tracing the zones of Cr-spinel growth, or they are present along the whole grain profile as cross-cutting veinlets forming a sieve texture. In general, pores become larger towards the outer grain boundary where they usually form round bubbles (Fig. $3 \mathrm{~J})$. Within the sieve spinels, worm-shaped pores are widespread and mostly filled with an unknown material which could not be analysed by electron microprobe. The chemical composition of individual grains in the centre-rim direction is nearly unchanged. They are represented either by magnesiochromite that from its chemical composition shows a peridotite origin or by chromite which indicates a volcanic origin (sensu Kamenetsky et al., 2001).

\section{DISCUSSION}

\section{INCLUSIONS AND ALTERATION IN CHROMIAN SPINELS}

As well as common inclusions, there is also unusual chromio-pargasite. A high content of $\mathrm{Cr}_{2} \mathrm{O}_{3}$ in the chromio-par- gasite inclusion may be caused by host-spinel contamination. On the other hand, $\mathrm{SiO}_{2}$ content in the host $\mathrm{Cr}$-spinel is negligible indicating no submicroscopic silicate phases in the place of dissolved elements (Burkhard, 1993; Barnes, 2000) and the $\mathrm{NiO}_{2}, \mathrm{ZnO}$ and $\mathrm{MnO}$ contents in the spinel are rather low. Nevertheless, the existence of another chlorite inclusion trapped within the same chromite (Fig. 3C) indicates alteration. Various types of inclusion have been described in both unaltered and altered zones of chromite grains in ophiolitic chromitites (Melcher et al., 1997). It was observed that some of these inclusions contained chlorite, interpreted as formed during metamorphism or serpentinisation, and then enclosed by recrystallising chromite during grain-boundary migration. If a grain of altered chromite is heated enough, it can recrystallise as a new homogeneous chromite with the same composition as the original chromite (Gervilla et al., 2012). This explains why many chromites, with homogeneous textures and compositions similar to primary chromite, contain polyphase inclusions. Multiple cycles of alteration/re-equilibration of the host-ultramafic rocks might have produced several events of dissolution-precipitation-homogenisation of grains (González-Jiménez et al., 2014). Chromio-pargasite is known from podiform chromitite deposits scattered in serpentinised dunite associated with rocks of eclogite metamorphic facies formed during retrograde metamorphism (Nishio-Hamane et al., 2012).

The composition of an olivine inclusion in a magnesiochromite (BZK-700 sample, Rača Unit) corresponds to that of olivine from upper mantle ultrabasic rocks and may have been derived from a nearly primitive magma. Its increased $\mathrm{Mg}$ content corresponds to the composition of spinels documenting genesis in ophiolite complexes.

From the geochemical features, the altered chromian spinels occurring in the Magura flysch deposits are a result of serpentinisation and regional metamorphism processes within their parental ultramafic rocks (Eales et al., 1988; Jan and Windley, 1990; Burkhard, 1993; Mellini et al., 2005; Mikuš and Spišiak, 2007; Farahat, 2008; González-Jiménez et al., 2009). The best-known feature of alteration patterns in Cr-spinel is the presence of $\mathrm{Fe}$-rich rims (ferritchromite) with a higher reflectivity (Fig. 3G) and depletion in some major elements (Cr, Al, Mg), due to element exchange and modification with the surrounding silicate minerals such as olivine and pyroxene (e.g., Lipin, 1984; Kimball, 1990; Merlini et al., 2009; Saumur and Hattori, 2013) in the source mafic-ultramafic rocks. The chemical compositions of some $\mathrm{Cr}$-spinel grains are consistent with the trend typical of metamorphosed chromites that are expressed as $\mathrm{Mg}$ and $\mathrm{Al} \mathrm{im-}$ poverishment, mainly compensated by increases in $\mathrm{Fe}^{2+}$ and/or $\mathrm{Fe}^{3+}$ (Khalil and El-Makky, 2009; González-Jiménez et al., 2009), though their high $\mathrm{Cr}$ content. The parental rocks were subjected to a sub-greenschist to greenschist facies metamorphic overprint (Barnes, 2000; González-Jiménez et al., 2009). The altered Cr-spinel group, due to significant changes in the content of discriminant elements, cannot be used for petrogenetic purposes.

A specific feature of the Cr-spinels analysed is the sieve texture (Fig. 3J). Given the almost identical chemical composition of the Cr-spinel in its centre and at the rim, along with internal areas of the grain with a sieve texture, we infer mineral breakdown induced by decompression with relatively little loss of heat as magma entered a shallow magma reservoir (Stormer, 1972; Nelson and Montana, 1992; Su et al., 2011). This texture is distinctive, especially in Cr-spinels from the Krynica Unit. 


\section{PROVENANCE OF DETRITAL SPINELS}

Cr-spinels in heavy mineral spectra signal a component of mafic to ultramafic rocks in the source material. A significant amount of $\mathrm{Cr}$-spinels in deposits from the southernmost areas of the Magura Basin was shown by Starobová (1962), and later by Winkler and Ślączka (1992, 1994) and Oszczypko and Salata (2005), which involved a source in re-sedimented material from the Pieniny Klippen Belt, perhaps even from the Magura Basin basement (Oszczypko and Salata, 2005; cf. Schmid et al., 2008: plate 1; Cieszkowski et al., 2010; Oszczypko et al., 2015). The preliminary microchemical data obtained from the Magura Fm. sandstones (Krynica Unit) show that the spinels are quite similar to those from the Eocene succession of the Krappfeld Gosau Group suggesting that Cr-spinels occuring in the OWC were supplied from ophiolites with harzburgitic affinity (Vardar Zone sub-province, Lenaz et al., 2001). Oszczypko and Salata (2005) analysed Cr-spinels from sandstones of the Rača and Bystrica units (Szczawina Fm.), the Krynica Unit (Szczawnica Fm.) and the Jarmuta Fm. sandstones belonging to the PKB. The spinels investigated did not show compositional zoning, chemical variability or inclusions

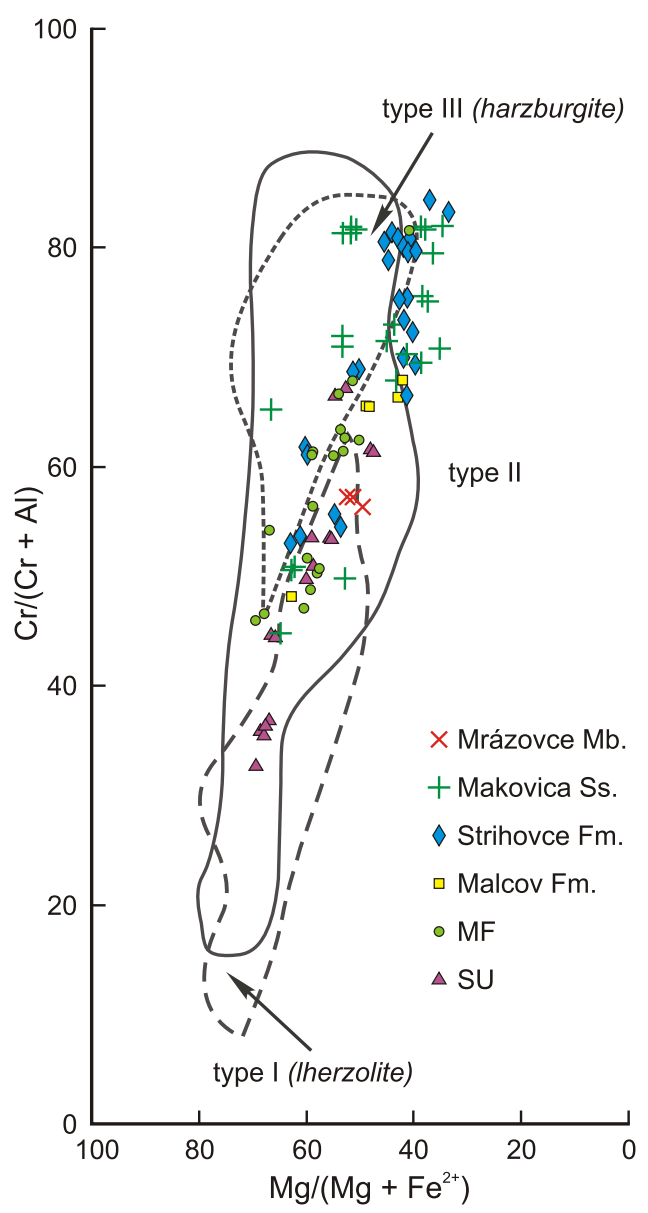

Fig. 6. Relationship between $\mathrm{Mg} /\left(\mathrm{Mg}+\mathrm{Fe}^{2+}\right)$ vs. $\mathrm{Cr} /(\mathrm{Cr}+\mathrm{Al})$ in the peridotitic spinels

Compositional fields are used according to Dick and Bullen's (1984) classification and admixtures of other phases. Based on their chemical composition Oszczypko and Salata (2005) noted an origin in ophiolite sequences or Alpine type peridotites. They attribute the Cr-spinel heterogeneous compositions to the gradual erosion of rocks building an ophiolite complex.

In this study, the chemistry of the unaltered Cr-spinels, with $\mathrm{TiO}_{2}$ content $<0.2 \mathrm{wt} . \%$, shows a peridotite origin (the first group). There is a set of relatively low $\mathrm{Al}_{2} \mathrm{O}_{3}$ and medium $\mathrm{Mg}$ (Mg\# 37-67 mol\%) contents; Cr\# varies in a wide range of 45-70 mol\%. Spinels of this composition correspond to supra-subduction zone peridotite (so-called SSZ) sensu Kamenetsky et al. (2001). According to Dick and Bullen's (1984) classification, they represent mainly intermediate type II and type III - harzburgites. Some points plot in the field of type I - Iherzolites (Fig. 6). Cr-spinels from SSZ peridotite occur in the Rača and Krynica units, respectively. The nature of the inclusions clearly confirms their provenance in ultramafic bodies.

Cr-spinels with $\mathrm{TiO}_{2}$ contents $>0.2$ wt. $\%$ denote the second group. They indicate a volcanic source. According to Lenaz et al. (2000), we discriminate between peridotitic and volcanic spinels on the basis of their $\mathrm{TiO}_{2}$ content and $\mathrm{FeO} / \mathrm{Fe}_{2} \mathrm{O}_{3}$ ratio. Lenaz et al. (2000) pointed out that peridotitic spinels show $\mathrm{TiO}_{2}$ content $<0.2$ wt. $\%$ and $\mathrm{FeO} / \mathrm{Fe}_{2} \mathrm{O}_{3}$ ratio $>3$, while spinels crystallised from basaltic magmas show $\mathrm{TiO}_{2}$ content $>0.2 \mathrm{wt} \%$ and $\mathrm{FeO} / \mathrm{Fe}_{2} \mathrm{O}_{3}$ ratio $<4$. Cr-spinels originating from cumulate and extrusive volcanic rocks tend to have higher $\mathrm{TiO}_{2}$ (Kamenetsky et al., 2001). The $\mathrm{Al}_{2} \mathrm{O}_{3}$ content is more variable. It reaches of $17-30$ wt.\% (rarely 50 wt.\%) in the Rača Unit. Slightly higher values (18-39 wt.\%) are shown in Cr-spinels from the Krynica Unit. Volcanic Cr-spinels from the Rača Unit represent spinels from basalts of BABB and/or MORB. Volcanic spinels from MOR basalts dominate in deposits from the Krynica Unit (Fig. 5).

In terms of chemical composition, there is some difference between Cr-spinels from the Magura Unit compared to Cr-spinels from Czorsztyn (Aubrecht et al., 2009) and Meliata units (Mikuš and Spišiak, 2007; Fig. 7), perhaps even to the Poruba flysch Fm. located in the Tatric and Fatric (Križna Nappe) units (Mikuš et al., 2006), which are considered a Meliata melange (Mikuš et al., 2006; Aubrecht et al., 2009).

Increased $\mathrm{TiO}_{2}$ and $\mathrm{FeO}$ contents are noticeable in most $\mathrm{Cr}$-spinels investigated from the Magura flysch formations. High $\mathrm{Fe}^{3+}$ and $\mathrm{TiO}_{2}$, along with lower Mg\#, suggest that $\mathrm{Cr}$-spinels

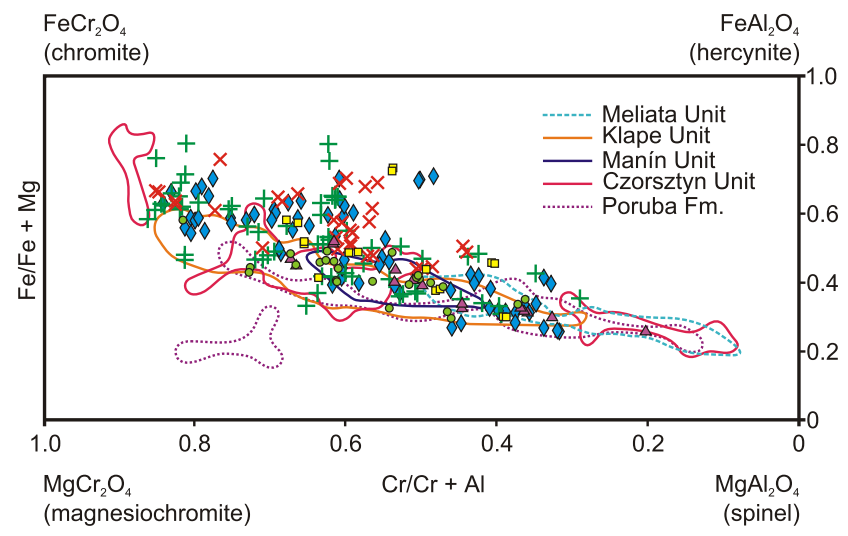

Fig. 7. Nomenclature and composition of spinels based on the classification of Deer et al. (1992)

The spinels studied are compared with the compositional fields of spinels from the Meliata, Klape and Manín and Czorsztyn units (according to Aubrecht et al., 2009 with references therein); explanations as for Figure 4 
could be the product of fractional crystallisation and re-equilibration at lower temperatures due to slow cooling (Arai, 1992; Kamenetsky et al., 2001; Lužar-Oberiter et al., 2009), and thus probably derived from cumulate members of the ophiolite source. On the other hand, high $\mathrm{Fe}^{3+}$ and increase of $\mathrm{Fe}$ at the expense of $\mathrm{Cr}$ simultaneously is typical of alteration processes. Altered spinels associated with serpentine may show increasing $\mathrm{Fe}^{2+}$ content from core to rim but $\mathrm{Cr}$ need not show the gain (Liipo et al., 1994).

Cr-spinels derived from volcanic rocks are moderately common (representing $40-44 \%$ of the spinels investigated) in the Magura flysch formations; nevertheless, peridotite spinels dominate in the Czorsztyn (Aubrecht et al., 2009) and Meliata units (Mikuš and Spišiak, 2007). Increased amounts of oxides (for example $\mathrm{TiO}_{2}$ ) may have been caused by alteration. However, the grains analysed of volcanic origin have optically and chemically homogeneous compositions (Fig. 3A). Significant decrease in $\mathrm{Al}_{2} \mathrm{O}_{3}, \mathrm{MgO}$ and $\mathrm{Cr}_{2} \mathrm{O}_{3}$, which might result from the alteration of Cr-spinels (Burkhard, 1993; Power et al., 2000; Spišiak et al., 2000, 2001; Mikuš et al., 2006; Mikuš and Spišiak, 2007; González-Jiménez et al., 2009), has not been observed in these grains.

Some Cr-spinels obtained from recent alluvial deposits occur in the Peri-Klippen zone of the Magura Unit (the bedrock of the recent fluvial system is composed of the Strihovce Fm.) show coincidence with those of the Czorsztyn or Meliata units (Fig. 5). The same composition of Cr-spinels was observed in the Jarmuta and Szczawnica formations (Oszczypko and Salata, 2005; cf. Fig. 5).

Spišiak et al. (2001) considered that $\mathrm{Cr}$-spinels from the Šambron flysch Zone (belonging to the Central Carpathian Paleogene Basin, CCPB) have been derived from two sources at least, although they included the possibility of resedimentation. According to Spišiak et al. (2001), the spinels investigated resemble the spinels derived from ultrabasic rocks from the Zbudza and Merník localities belonging to the Iňačovce-Krichevo Unit (Soták et al., 1990, 1991, 1995), or from ultrabasic rocks cropping out in Gemericum, as well as the spinels from the PKB or the Magura Unit. However, low Ti contents in Cr-spinels from the Zbudza and Merník localities (Spišiak et al., 2001) are notable. Moreover, the contents of major oxides $\left(\mathrm{Cr}_{2} \mathrm{O}_{3}, \mathrm{Al}_{2} \mathrm{O}_{3}\right)$ are not the same. A heterogeneous character of $\mathrm{Cr}$-spinels in the Šambron Zone sediments was also noted by Lenaz et al. (2001, 2009). Peridotite spinels are prevalent (representing $90 \%$ of the spinels derived from peridotite of type II sensu Dick and Bullen,1984), while scattered volcanic spinels have OIB character (Lenaz et al., 2009). Lenaz et al. (2009) inferred the similarity with spinels from the Vardar Zone. We do not consider the lňačovce-Krichevo Unit as a possible source of ultrabasic material since its outcrop and exhumation are datable to the Early Miocene based on the FT zircon age (Soták et al., 2000, 2005). The subsidence of the CCPB reached its peak during the Eocene (Kováč et al., 1994). In addition, the Cr-spinels analysed from the Magura flysch deposits show some differences compared with those from the lňačovce-Krichevo Unit (Fig. 5). An absence of serpentine is apparent in the heavy mineral spectra from the Magura formations (in eastern Slovakian part), while it is a major component of sandstones from the Šambron flysch Zone (Spišiak et al., 2001).

Consideration of re-eroded sediments from the Pieniny Klippen Belt s.I. or more precisely from the Czorsztyn Ridge realm (Winkler and Ślączka, 1994), as a possible source of the Cr-spinels present in the Magura Basin deposits could not be absolutely excluded, but only for deposits forming except the
Eocene. Eocene conglomerates of the Strihovce Fm. (Krynica Unit) contain no material from the PKB (Czorsztyn succession, Mišík et al., 1991b; Oszczypko et al., 2015). They originated from a source that was situated between the Magura flysch and Klippen sedimentary areas (South-Magura cordillera sensu Marschalko, 1975; Marschalko et al., 1976). Oszczypko and Oszczypko-Clowes (2006) suggested that the provenance of these rocks may be connected with the Eocene exhumation of the Magura Basin basement (Valais-Rhenodanubian-Magura oceanic accretionary prism sensu Schmid et al., 2008) or possibly with the Inner Carpathian realm represented by the Inner Dacides and/or Tisza terrain (Oszczypko et al., 2006). Considering the character of the Cr-spinels and their presence within subjacent formations, redeposition from the PKB during the Paleocene and/or during the Oligocene may be presumed. Sporadic volcanic Cr-spinel compositions appear to be more heterogeneous in this realm. It changed from ARC to MORB (Lenaz et al., 2009). The volcanic spinels from the Malcov Fm. deposits (Upper Eocene-Upper Oligocene) show some similarity to the spinels from the Poruba Fm. in the Križna Nappe (Bónová et al., 2016). Cr-spinels from the Poruba Fm. show an affinity to the Meliata ocean (Mikuš et al., 2006). Aubrecht et al. (2009) proposed the same origin for Cr-spinels of the Czorsztyn Unit (PKB). They considered the exotic Andrusov Ridge, representing the Meliata melange supplying the Central Carpathian zone in the south, and Oravicum (later the PKB) in the north by ophiolitic detritus simultaneously. Cr-spinels from the Jarmuta Fm. (Maastrichtian-Paleocene) located along the tectonic boundary between the PKB and the Krynica Unit and from the Szczawnica Fm. (Paleocene-Lower Eocene) that represents a typical lithofacies of the Krynica Unit with harzburgitic (or less commonly Iherzolitic) affinity, show similar characteristics indicating a source in material from the PKB (Oszczypko and Salata, 2005; Fig. 5). The chemical composition of Cr-spinels from the Meliata Unit suggests the Iherzolitic patterns, while harzburgitic parent rocks have not been confirmed (Mikuš and Spišiak, 2007).

The supply of Cr-spinels with the same chemical signature remained dominant from the Eocene until the earliest Oligocene in the Magura Basin, suggesting that exposed remnants of the same ophiolite belt persisted through the Eocene to the Early Oligocene and that recycling was significant. A directional change in composition of the detrital chromian spinels from the south (Krynica Unit) to the north (Rača Unit) is not evident, although the sedimentation areas of both units had already developed in the Eocene. Indeed, palaeoflow analysis indicates the source of sedimentary material from the NW in the Mrázovce Member (Beloveža Fm., Rača Unit; Kováčik and Bóna, 2005). Palaeotransport from the SE is predominant in the Makovica Sandstones (Zlín Fm.), while less significant palaeocurrent traces were observed from the $E$ in this formation (Koráb et al., 1962; Kováčik et al., 2009, 2011) and siliciclastic deposits of the Krynica Unit were supplied generally from the SE (Koráb et al., 1962; Bónová et al., 2010; Kováčik et al., 2011) and to a lesser extent from the south (Mišík et al., 1991b). Nevertheless, in term of spinel geochemical composition from the Rača (Mrázovce Mb. versus Makovica Ss.) and Krynica (Strihovce Fm.) units, respectively, the possibly different provenance is either not evident (Fig. 5) or the Cr-spinel seems not to be sufficiently discriminatory. Another explanation is the considerable longitudinal (axial) direction of entrance for the ophiolite detrital material into the Magura Basin.

For the Krynica Unit, association of Cr-spinels with radiolarites in the Strihovce Fm. deposits (Mišík et al., 1991b) is a re- 
liable indicator of the presence of an ophiolite complex representing a relict of oceanic crust among the source material. Considering the ubiquity of $\mathrm{Cr}$-spinels but the lack of the ophiolitic lithoclasts, a source area consisting of obducted ophiolites must have been a certain distance from the Magura Basin.

For the Rača Unit, the presence of gabbro olistoliths in the Osielec sandstones, which was primarily described by Wieser (1952) as "the ophiolite from Osielec", may represent an ophiolite succession indicating oceanic crust (Cieszkowski et al., 2010).

Taking into account the geochemical characteristics of the Cr-spinels and palaeoflow directions (in the Eocene especially) we consider that the source of $\mathrm{Cr}$-spinels may have been the ophiolite complexes of the Fore-Marmarosh Suture Zone (Hnylko, 2011) represented by structural-facies units such as the Kamyanyi Potik, Rakhiv and Sukhiv-Burkut (Porkulets) nappes incorporating the Trostyanets and Rakhiv-Chyvchyn magmatic complexes. These magmatic complexes, located in the Eastern Flysch Carpathians north of the Marmarosh Massif, consist of basic effusive rocks (basaltoids) formed on transitional and oceanic crust (Hnylko and Vashchenko, 2004; Lyashkevich and Yatsozinskiy, 2005; Pavlyuk et al., 2013, 2014). The Trostyanets Complex is built of volcanic rocks of the ophiolitic association though the picrites and basalts have an alkaline character and were formed in the conditions of intracontinental rifting (Lyashkevich et al., 1995; Varishchev, 1997; Generalova et al., 2013). Based on their geochemical composition, Stupka et al. (2011) suggested that they belong to early volcanic rocks that developed on an ensialic substrate. On the other hand, the Rakhiv and Sukhiv-Burkut nappes contain remnants of Jurassic-Neocomian mafic rocks. These rocks and basalts of the Kamyanyi Potik Unit are partly of oceanic origin according to petrochemical data (Lyashkevich et al., 1995; Varishchev, 1997). The Kamyanyi Potik, Rakhiv and Sukhiv-Burkut nappes (Fore-Marmarosh Suture Zone) belong to the suture and originated from the oceanic realm and likely correspond to the Outer Dacides-Severinides (Ślączka et al., 2006; Golonka et al., 2008; Săndulescu, 2009). The Kamyanyi Potik Unit is most probably a prolongation of the Black Flysch Unit of the Romanian Carpathians (Ślaczka et al., 2006; Hnylko et al., 2015a). The Rakhiv and Sukhiv-Burkut nappes are likely continuations of the Ceahlau Unit (Ślączka et al., 2006; Balintoni and Balica, 2013; Oszczypko et al., 2015). The basement of the Ceahlau-Severin Basin crops out mainly in the Severin Nappe (South Carpathians) and consists of strongly dismembered ophiolitic lithologies (Savu et al., 1985) such as harzburgitic (rarely lherzolitic) ultramafic rocks, gabbros and pillow basalts. The blocks of ophiolitic material were found embedded in coarse-grained clastic deposits of Late Jurassic and Cretaceous age. The Severin-Ceahlau ophiolites are thought to be remnants of an intracontinental oceanic basin within the European margin (Hoeck et al., 2006).

Chromites from ultrabasic rocks outcropping in the Velyka and Mala Uholka River valley (Uholskyi Complex, PKB in the Ukrainian Carpathians) are also known (Bilonizhka et al., 1995; Lyashkevich et al., 1995).

The ophiolite material now present as olistoliths in the Vezhany Nappe (Marmarosh Klippen Zone; Hnylko and Hnylko, 2016) may have partially sourced the younger (Oligocene) flysch deposits of the Magura Basin (Malcov Fm.). The
Vezhany Nappe is located to the northwest of the Marmarosh Crystalline Massif. This nappe is thrust over the Cretaceous flysch of the Outer Carpathians. The lower part of the Vezhany stratigraphic succession (Soymul Fm.) is represented by an Early Cretaceous olistostrome (in places an olistostrome-conglomerate) with olistoliths of Proterozoic(?)-Paleozoic-Mesozoic rocks derived from the Marmarosh Massif as well as olistoliths of Mesozoic mafic-ultramafic rocks and also of Lower Cretaceous organogenic Urgonian-type limestones (Hnylko and Hnylko, 2016). Olistoliths of an ophiolitic association are formed by serpentinised peridotites with spinels (Iherzolites, harzburgites and websterites). A volcanic assemblage formed of metadolerites, picritic basalts, basalts and so on is an integral element of the ophiolite association (Hnylko et al., 2015b). Sedimentological data from the Paleocene-lowermost Oligocene Vezhany succesion (Metova Fm.) support the conclusions based on foraminifera, indicating a bathyal environment (Hnylko et al., 2015a; Hnylko and Hnylko, 2016) and during deposition of the Eocene succession in the Magura Basin the ophiolitic association of the Vezhany Nappe could not have been the source for Cr-spinels. Ophiolite complexes of the Vezhany Nappe are probably remnants of the Transylvanian-Mures (Vardar-Mures) Suture Zone (Csontos and Vörös, 2004; Schmid et al., 2008) formed after collision of the Tisza and Dacia Mega-units (Schmid et al., 2008; Hnylko et al., 2015b).

\section{CONCLUSIONS}

Detrital chromian spinel grains in the Eocene to Oligocene Magura flysch successions display relatively high $\mathrm{Cr} \#$ and $\mathrm{TiO}_{2}$. Detrital spinels in these formations were derived from peridotitic and volcanic source rocks, respectively and can be discriminated on the basis of their $\mathrm{TiO}_{2}$ and $\mathrm{Fe}$ contents. Altered chromian spinels were also distinguished. The ophiolite source consisted of harzburgitic mantle peridotites and was developed mainly in a supra-subduction zone setting.

Palaeogeographic reconstructions based on the geochemistry of the Cr-spinels (supported by published palaeoflow data) suggest that during the Eocene to Early Oligocene the source area of ophiolitic detritus for the eastern part of the Magura Basin was most probably located in the Fore-Marmarosh Suture Zone (Eastern Carpathians) that is considered an equivalent of the Black Flysch and Ceahlau units. Ophiolitic material attached to sedimentary rocks of the PKB, which is regarded as the Meliata melange, is not indicated unambiguously as a source for Cr-spinels in the Eocene flysch deposits of the Magura Basin. Although a certain proportion of $\mathrm{Cr}$-spinels found in the Eocene deposits may have been resedimented from oldest Cretaceous-Paleocene successions of the Magura Basin, which are considered to represent reworking of sedimentary material from the PKB.

Unusual inclusion of chromio-pargasite in chromite indicates the metamorphism of its source rocks in the retrograde stage of serpentinisation of a dunite body metamorphosed to eclogite facies.

The results presented in this contribution are still preliminary and require further comparison with the neighbouring areas, primarily with the Ukrainian Eastern Carpathians. 
Acknowledgements. The research was partially supported by a project of Ministry of the Environment of the Slovak Republic - 0306 "Geological map of the Nízke Beskydy Mts. the western part at 1:50,000 scale" and project VEGA 1/0650/15. The authors thank Assoc. Prof. R. Aubrecht from Comenius University, Dr. O. Hnylko from the National Academy of Sciences of Ukraine and Dr. D. Salata from the Institute of
Geological Sciences of the Jagiellonian University for helpful comments and recommendations. The authors are also grateful to Editor-in-Chief Prof. T.M. Peryt for thorough editorial handling and to Dr. J. Zalasiewicz for linguistic improvement of the final text.

\section{REFERENCES}

Arai, S., 1992. Chemistry of chromian spinel in volcanic rocks as a potential guide to magma chemistry. Mineralogical Magazine, 56: 173-184.

Aubrecht, R., Méres, Š., Sýkora, M., Mikuš, T., 2009. Provenance of the detrital garnets and spinels from the Albian sediments of the Czorsztyn Unit (Pieniny Klippen Belt, Western Carpathians, Slovakia). Geologica Carpathica, 60: 463-483.

Balintoni, I., Balica, C., 2013. Carpathian peri-Gondwanan terranes in the East Carpathians (Romania): a testimony of an Ordovician, North-African orogeny. Gondwana Research, 23: 1053-1070.

Barnes, S.J., 2000. Chromite in komatiites, II. Modification during greenschist to mid-amphibolite facies metamorphism. Journal of Petrology, 41: 387-409.

Bilonizhka, P.M., Gritsik, V.V., Ivantishina, O.M., Lyashenko, V.S., Manichev, V.I., Matkovskyi, O.I., Petrichenko, O.I., Remeshilo, B.G., Skakun, L., Khmelevskiy, V.A., Fenoshina, U.I., Yantschuk, E.A., Yasinskaya, A.A., 1995. Minerals of Ukrainian Carpathians. Oxides, hydroxides, chlorites, fluorides, jodides (in Ukrainian). LNU imeni Ivana Franka Lviv.

Bónová, K., Bóna, J., Kováčik, M., Siráňová, Z., 2010. Detritické granáty, turmalíny a zirkóny sedimentov strihovského súvrstvia krynickej jednotky (magurský príkrov): ich chemické zloženie a možný pôvod (in Slovak). In: Geochémia 2010: zborník vedeckých príspevkov z konferencie (eds. I. Slaninka, L'. Jurkovič and O. Ďurža): 29-32. Štátny Geologický Ústav Dionýza Štúra, Bratislava.

Bónová, K., Bóna, J., Kováčik, M., Laurinc, D., 2016. Heavy minerals from sediments of the Malcov Formation and their palaeogeographic implications for the Magura Basin evolution during the Late Eocene-Late Oligocene (Western Carpathians, Slovakia). Geological Quarterly, 60 (3): 675-694.

Burkhard, D.J.M., 1993. Accessory chromium spinels: Their coexistence and alteration in serpentinites. Geochimica et Cosmochimica Acta, 57: 1297-1306.

Cieszkowski, M., Kysiak, T., Ślączka, A., Wolska, A., 2010. Olistoliths of gabbro from Osielec (Magura Nappe, Outer Carpathians, Poland). Mineralia Slovaca (Geovestník), 4: 507-508.

Csontos, L., Vörös, A., 2004. Mesozoic plate tectonic reconstruction of the Carpathian region. Palaeogeography, Palaoclimatology, Palaeoecology, 210: 1-56.

Deer, W.A., Howie, R.A., Zussman, J., 1992. An Introduction to the Rock-Forming Minerals. Longman, 2-nd.

Deer, W.A., Howie, R.A., Zussmann, J., 1997. Rock-forming minerals, 1A: Orthosilicates. The Geological Society, London.

Dick, H.J.B., Bullen, T., 1984. Chromian spinel as a petrogenetic indicator in abyssal and alpine-type peridotites and spatially associated lavas. Contribution to Mineralogy and Petrology, 86: $54-76$.

Eales, H.V., Wilson, A.H., Reynold, I.M., 1988. Complex unmixed spinels in layered intrusions within an abducted ophiolite in the Natal-Namaqua mobile belt. Mineralia Deposita, 23: 150-157.

Farahat, E.S., 2008. Chrome-spinels in serpentinites and talc carbonates of the El Ideid-El-Sodmein District, central Eastern Desert, Egypt: their metamorphism and petrogenetic implications. Chemie der Erde, 68: 193-205.
Generalova, L., Pashchenko, V., Stepanov, V., 2013. Some features of the volcanites chemistry of the Trostyanetsky Mesozoic Complex (Ukrainian Carpathians) (in Ukrainian with English summary). Visnyk of the Lviv University, series Geology, 27: 104-115.

Geological map of Slovakia at scale 1:50 000 [online]. Bratislava: Štátny geologický Ústav Dionýza Štúra, 2013. [cit. 18. 03. 2015]. Available on the internet: http://mapserver.geology.sk/gm50js

Gervilla, F., Padrón-Navarta, J.A., Kerestedjian, T., Sergeeva, I., González-Jiménez, J.M., Fanlo, I., 2012. Formation of ferrian chromite in podiform chromitites from the Golyamo Kamenyane serpentinite, Eastearn Rhodopes, SE Bulgaria: a two-stage process. Contribution to Mineralogy and Petrology, 164: 643-657.

Golonka, J., Krobicki, M., Waśkowska-Oliwa, A., Vašíček, Z., Skupien, P., 2008. Main paleogeographic elements of the West Outer Carpathians during Late Jurassic and Early Cretaceous times. Geologia, 34: 61-72.

González-Jiménez, J.M., Kerestedjian, T., Profenza, J.A., Gervilla, F., 2009. Metamorphism on chromite ores from the Dobromirtsi Ultramafic Massif, Rhodope Mountains (SE Bulgaria). Geologica Acta, 7: 413-429.

González-Jiménez, J.M., Griffin, W.L., Gervilla, F., Proenza, J.A., O'Reilly, S.Y., Pearson, N.J., 2014. Chromitites in ophiolites: How, where, when, why? Part I. A review and new ideas on the origin and significance of platinum-group minerals. Lithos, 189: 127-139.

Hawthorne, F.C., Oberti, R., Harlow, G.E., Maresch, W.V., Martin, R.F., Schumacher, J.C., Welch, M.D., 2012. Nomenclature of amphibole supergroup. American Mineralogist, 97: 2031-2048.

Hnylko, O.M., 2011. Tectonic zoning of the Carpathians in terms of the terrane tectonics. Section 1. Main units of the Carpathian Building (in Ukrainian with English summary). Geodynamika, 10: $47-57$

Hnylko, O., Vashchenko, V.O., 2004. The Trostyanets basaltoids in the structure of the Eastern Carpathian Flysch Belt (in Ukrainian with English summary). Geologiya i Geokhimiya Goryutchych Kopalyn, 1: 77-84.

Hnylko, O., Krobicki, M., Feldman-Olszewska, A., Iwańczuk, J., 2015a. Geology of the volcano-sedimentary complex of the Kamyanyi Potik Unit on Chyvchyn Mountain (Ukrainian Carpathians): preliminary results. Geological Quarterly, 59 (1): 145-156.

Hnylko, O.M., Hnylko, S.R., Generalova, L.V., 2015b. Formation of the structure of the Klippen zones and the interklippen flysch of inner Ukrainian Carpathians - results of convergence and collision of microcontinental terranes (in Russian with English summary). Vestnik of Saint Petersburg University, series 7, Geology, 2: 4-24.

Hnylko, S., Hnylko, O., 2016. Foraminiferal stratigraphy and palaeobathymetry of Paleocene-lowermost Oligocene deposits (Vezhany and Monastyrets nappes, Ukrainian Carpathians). Geological Quarterly, 60 (1): 75-103.

Hoeck, V., lonescu, C., Koller, F., 2006. Mesozoic ophiolites in the Dinarides and the Carpathians: a review. Acta Mineralogica-Petrographica, Abstract-Series, 5: 39-41. 
Hovorka, D., Ivan, P., Jaroš, J., Kratochvíl, M., Reichwalder, P., Rojkovič, I., Spišiak, J., Turanová, L., 1985. Ultramafic Rocks of the Western Carpathians, Czechoslovakia. Geological Institute of Dionýz Štúra, Bratislava.

Jablonský, J., Sýkora, M., Aubrecht, R., 2001. Detritické Cr spinely v sedimentárnych horninách mezozoika Západných Karpát (prehlad nových poznatkov) (in Slovak). Mineralia Slovaca, 33: 487-498.

Jan, M.Q., Windley, B.F., 1990. Chromian spinel-silicate chemistry in ultramafic rocks of the Jijal complex, northwest Pakistan. Journal of Petrology, 31: 667-715.

Kamenetsky, V.S., Crawford, A.J., Meffre, S., 2001. Factors controlling chemistry of magmatic spinel; an empirical study of associated olivine, $\mathrm{Cr}$-spinel and melt inclusions from primitive rocks. Journal of Petrology, 42: 655-671.

Khalil, K.I., El-Makky, A.M., 2009. Alteration mechanisms of chromian-spinel during serpentinization at Wadi Sifein Area, Eastern Desert, Egypt. Resource Geology, 59: 194-211.

Kimball, K.L., 1990. Effects of hydrothermal alteration on the composition of chromian spinels. Contributions to Mineralogy and Petrology, 105: 337-346.

Koráb, T., 1983. Geological map of the Nízke Beskydy Mts - Eastern Part $(1: 50,000)$ (in Slovak). Geological Institute of Dionýz Štúr, Bratislava.

Koráb, T., Nemčok, J., Ďurkovič, T., Marschalko, R., 1962 Prehl'adný výskum orientovaných sedimentárnych textúr vo flyši východného Slovenska (in Slovak). Geologický Sborník, 13: 257-274.

Kováč, M., Král', J., Márton, E., Plašienka, D., Uher, P., 1994. Alpine uplift history of the Central Western Carpathians: geochronological, paleomagnetic, sedimentary and structural data. Geologica Carpathica, 45: 83-96.

Kováčik, M., Bóna, J., 2005. Sedimentological character of lower part of Rača Unit Paleogene of Magura Nappe at Mrázovce (Outer Flysch Belt, Eastern Slovakia) (in Slovak with English summary). Mineralia Slovaca, 37: 310-314

Kováčik, M., Bóna, J., Bónová, K., Siráňová, Z., Derco, J., Žecová, K., 2009. Príspevok k sedimentológii a proveniencii makovických pieskovcov zlínskeho súvrstvia račianskej jednotky (magurský príkrov, východné Slovensko). In: Spoločný geologický kongres Českej a Slovenskej geologickej spoločnosti (eds. M. Kohút and L. Šimon): 107-108. Konferencie, sympóziá, semináre. Štátny Geologický Ústav Dionýza Štúra, Bratislava.

Kováčik, M., Bóna, J., Gazdačko, L'., Kobulský, J., Maglay, J., Kučera, M., 2011. Geological map of the Nízke Beskydy Mts. western part at 1:50,000 scale (in Slovak). Ministry of the Environment of the Slovak Republic, State Geological Institute of Dionýz Štúr, Bratislava.

Kováčik, M., Bóna, J., Gazdačko, L’., Kobulský, J., Maglay, J., Žecová, K., Derco, J., Zlinská, A., Siráňová, Z., Boorová, D., Bónová, K., Buček, S., Kucharič, L'., Kubeš, P., Bačová, N. Petro, L'., Vaněková, H., 2012. Explanation to the geological map of the Nízke Beskydy Mts. - western part at 1:50,000 scale (in Slovak). State Geological Institute of Dionýz Štúr, Bratislava.

Križáni, I., 1985. Výsledky šlichovania vo východoslovenskom kraji a možnosti ich využitia (in Slovak). Akcesorické Minerály, Domaša, Banícka Fakulta Vysokej Školy Technickej, Košice: 127-165.

Lenaz, D., Kamenetsky, V.S., Crawford, A.J., Princivalle, F., 2000. Melt inclusions in detrital spinel from the SE Alps (Italy-Slovenia): a new approach to provenance studies of sedimentary basins. Contributions to Mineralogy and Petrology, 139: 748-758.

Lenaz, D., Winkler, W., Reusser, E., Princivalle, F., 2001. Preliminary chemical data of detrital Cr-spinels from Polish Western Carpathians Flysch. In: Abstracts of 21st meeting IAS 2001 Davos (Switzerland).

Lenaz, D., Mazzoli, C., Spišiak, J., Princivalle, F., Maritan, L., 2009. Detrital Cr-spinel in the Šambron-Kamenica Zone (Slovakia): evidence for an ocean-spreading zone in the Northern Vardar suture? International Journal of Earth Sciences (Geologische Rundschau), 98: 345-355.
Lexa, J., Bezák, V., Elečko, M., Mello, J., Polák, M., Potfaj, M., Vozár, J., Schnabel, G.W., Pálenský, P., Császár, G., Ryłko, W., Mackiv, B., 2000. Geological map of Western Carpathians and adjacent areas $(1: 500,000)$. Ministry of the Environment of the Slovak Republic, Geological Survey of Slovak Republic, Bratislava.

Liipo, J., Vuollo, J., Nykänen, V., Piirainen, T., 1994. Chromite compositions as evidence for an Archean ophiolite in the Kuhmo greenstone belt in Finland. Bulletin of Geological Society of Finland, 66: 3-18.

Lipin, B.R., 1984. Chromite from the Blue Ridge Province of North Carolina. American Journal of Science, 284: 507-529.

Lyashkevich, Z.M., Yatsozinskiy, O.M., 2005. Alpiyskiy magmatism Ukrainskikh Karpat, ego evolutsia a geodinamika (in Russian with English summary). Geofizicheskiy Zurnal, 27: 1005-1011.

Lyashkevich, Z.M., Medvedev, A.P., Krupskiy, Y.Z., Varichev, A.S., Tymoshchuk, V.P., Stupka, O.O., 1995. Tectonomagmatic evolution of Carpathians (in Russian). Naukovaya Dumka, Kiev.

Locock, A.J., 2014. An Excel spreadsheet to classify chemical analyses of amphiboles following the IMA 2012 recommendations. Computers and Geosciences, 62: 1-11.

Lužar-Oberiter, B., Mikes, T., von Eynatten, H., Babic, L., 2009. Ophiolitic detritus in Cretaceous clastic formations of the Dinarides (NW Croatia): evidence from Cr-spinel chemistry. International Journal of Earth Sciences, 98: 1097-1108.

Marschalko, R., 1975. Sedimentologický výskum paleogénnych zlepencov bradlového pásma a prilahlých tektonických jednotiek a prostredie ich vzniku (in Slovak). Náuka o Zemi, Séria Geológia, 9: 148.

Marschalko, R., Mišík, M., Kamenický, L., 1976. Petrographie der Flysch-Konglomerate und Rekonstruktion ihrer Ursprungszonen (Paläogen der Klippenzone und der angrenzenden tektonischen Einkeiten der Ostslowakej). Západné Karpaty, Séria Geológia, 1: 7-124.

Matějka, A., Buday, T., Březina, J., Cicha, I., Čechovič, V., Čtyroký, P., Dornič, J., Eliáš, M., Fusán, O., Hanzlíková, E., Chmelík, F., Kuthan, M., Kvitkovič, J., Marschalko, R., Mazúr, E., Nemčok, J., Porubský, A., Pesl, V., Slavik, J., Straník, Z., Švagrovský, J., Zorkovský, B., 1964. Explanations to the General geological map of ČSSR 1:200,000, sheets M-34-XXII Zborov - M-34-XXVIII Košice (in Slovak). Publ. Ústredný Ústav Geologický, Bratislava.

Melcher, F., Grum, W., Simon, G., Thalhammer, T.V., Stumpfl, E.F., 1997. Petrogenesis of the ophiolitic giant chromite deposits of Kempirsai, Kazakhstan: a study of solid and fluid inclusions in chromite. Journal of Petrology, 38: 1419-1458.

Mellini, M., Rumori, C., Viti, C., 2005. Hydrothermally reset magmatic spinels in retrograde serpentinites, formation of "ferritchromit" rims and chlorite aureoles. Contributions to Mineralogy and Petrology, 149: 266-275.

Menčík, E., Pesl, V., 1959. Přehledné geologické mapování magurského flyše na východním Slovensku (in Czech). Zprávy o Geologických Výzkumech v, r. 1957: 181-186.

Merlini, A., Grieco, G., Diella, V., 2009. Ferritchromite and chromian-chlorite formation in mélange-hosted Kalkan chromitite (Southern Urals, Russia). American Mineralogist, 94: 1459-1467.

Mikuš, T., Spišiak, J., 2007. Chemical composition and alteration of Cr-spinels from Meliata and Penninic serpentinized peridotites (Western Carpathians and Eastern Alps). Geological Quarterly, 51 (3): 257-270

Mikuš, T., Spišiak, J., Sýkora, M., Demko, R., 2006. Chemical composition of spinels from Mesozoic alkali basalts of the Western Carpathians: implications for sources of detrital spinels in flysch sediments. Geologica Carpathica, 57: 447-460.

Mišík, M., Jablonský, J., Fejdi, P., Sýkora, M., 1980. Chromian and ferrian spinels from Cretaceous sediments of the Western Carpathians. Mineralia Slovaca, 42: 101-112.

Mišík, M., Sýkora, M., Mock, R., Jablonský, J., 1991a. Paleogene Proč conglomerates of the Klippen Belt in the West Carpathians. 
Material from Neopieninic Exotic Ridge. Acta Geologica Geographica Universitatis Commeniae, Geologia, 46: 9-101.

Mišík, M., Sýkora, M., Jablonský, J., 1991b. Strihovce Conglomerates and South-Magura Exotic Ridge (West Carpathians). Západné Karpaty, Séria Geológia, 14: 7-72.

Morimoto, N., Fabries, J., Ferguson, A.K., Ginzburg, V.I., Ross, M., Seifert, F.A., Zussman, J., Aoki, K., Gottardi, G., 1988. Nomenclature of pyroxenes. Mineralogical Magazine, $\mathbf{5 2}$ : 535-550.

Nelson, S.T., Montana, A., 1992. Sieve-textured plagioclase in volcanic rocks produced by rapid decompression. American Mineralogist, 77: 1242-1249.

Nemčok, J., 1990. Geologická mapa Pienin, Čergova, L'ubovnianskej a Ondavskej vrchoviny v mierke 1:50,000 (in Slovak). Geologický Ústav Dionýza Štúra, Bratislava.

Nemčok, J., Koráb, T., 1963. Contribution to the geology of Smilno tectonic window and adjacent part of the Magura flysch. Geologický Sborník, 14: 209-215.

Nemčok, J., Zakovič, M., Gašpariková, V., Ďurkovič, T., Snopková, P., Vrána, K., Hanzel, V., 1990. Vysvetlivky ku geologickej mape Pienin, Čergova, L'ubovnianskej a Ondavskej vrchoviny v mierke 1:50,000 (in Slovak). Geologický Ústav Dionýza Štúra, Bratislava.

Nishio-Hamane, D., Ohnishi, M., Minakawa, T., Yamaura, J-I., Saito, S., Kadota, R., 2012. Ehimeite, $\mathrm{NaCa}_{2} \mathrm{Mg}_{4} \mathrm{CrSi}_{6} \mathrm{Al}_{2} \mathrm{O}_{22}(\mathrm{OH})_{2}$ the first $\mathrm{Cr}$-dominant amphibole from the Akaishi Mine, HigashiAkaishi Mountain, Ehime Prefecture, Japan. Journal of Mineralogical and Petrological Sciences, 107: 17.

Oszczypko, N., Salata, D., 2005. Provenance analyses of the Late Cretaceous-Palaeocene deposits of the Magura Basin (Polish Western Carpathians) - evidence from a study of the heavy minerals. Acta Geologica Polonica, 55: 237-267.

Oszczypko, N., Oszczypko-Clowes, M., 2006. Evolution of the Magura Basin (in Polish with English summary). In: Palaeotectonic Evolution of the Outer Carpathian and Pieniny Klippen Belt Basins (eds. N. Oszczypko, A. Uchman and E. Malata): 133-164. Instytut Nauk Geologicznych Uniwersytetu Jagiellońskiego, Kraków.

Oszczypko, N., Oszczypko-Clowes, M., Salata, D., 2006. Exotic rocks of the Krynica Zone (Magura Nappe) and their palaeogeographic significance (in Polish with English summary). Geologia, 32: 21-45.

Oszczypko, N., Ślączka, A., Oszczypko-Clowes, M., Olszewska, B., 2015. Where was the Magura Ocean? Acta Geologica Polonica, 65: 319-344

Pavlyuk, M.I., Lyashkevich, Z.M., Medchociaż nie wiadomo czy beda miejsca vedev, A.P., 2013. Ukrainian Carpathians in the structure of PANCARDI (magmatism and geodynamics) (in Ukrainian with English summary). Geologija, Geodinamika, 1 47-60.

Pavlyuk, M.I., Lyashkevich, Z.M., Medvedev, A.P., 2014. PANCARDI magmatism and structure in Early Mesozoic (in Ukrainian with English summary). Geologija, Visnyk Kyivskogo Natsíonalnoho Universitetu imení Tarasa Shevchenka, 66 27-33.

Power, M.R., Pirrie, D., Andersen, J.C., Wheeler, P.D., 2000. Testing the validity of chromian spinel chemistry as a provenance and petrogenetic indicator. Geology, 28: 1027-1030.

Samuel, O., 1990. Unifikácia litostratigrafických jednotiek východoslovenského flyšu (in Slovak with English summary). Geologické Práce, Správy, 91: 61-74.

Săndulescu, M., 2009. The Black Flysch Nappe of the Maramureş East Carpathians - a "Valaisanne-type" tectonic unit? Geosciences, Tectonics, Proceeding of Romanian Academy, Series B, 1: 45-51.

Saumur, B.M., Hattori, K.H., 2013. Zoned Cr-spinel and ferritchromite alteration in forearc mantle serpentinites of the Rio San Juan Complex, Dominican Republic. Mineralogical Magazine, 77 : 117-136.
Savu, H., Udrescu, C., Neacşu, V., Bratosin, I., Stoian, M., 1985. Origin, geochemistry and tectonic position of the Alpine ophiolites in the Severin Nappe (Mehedinti Plateau, Romania). Ofioliti, 10: 423-440.

Schmid, S.M., Bernoulli, D., Fügenschuh, B., Matenco, L., Schefer, S., Schuster, R., Tischler, M., Ustaszewski, K., 2008. The Alpine-Carpathian-Dinaridic orogenic system: correlation and evolution of tectonic units. Swiss Journal of Geosciences, 101: 139-183.

Ślączka, A., Kruglov, S., Golonka, J., Oszczypko, N., Popadyuk, I., 2006. Geology and hydrocarbon resources of the Outer Carpathians, Poland, Slovakia, and Ukraine: general geology. AAPG Memoir, 84: 221-258.

Soták, J., Križáni, I., Spišiak, J., 1990. On position and material composition of the Mernik conglomerates (the Central Carpathian Paleogene). Acta Geologica Universitates Comenianae, Geologica, 45: 117-125.

Soták, J., Križáni, I., Spišiak, J., 1991. Stratigrafická pozícia a sedimentológia merníckych zlepencov (in Slovak). Geologické Práce, Správy, 92: 53-69.

Soták, J., Biroň, A., Kotulová, J., Rudinec, R., Spišiak, J., 1995. Geological structure of the East Slovakian basin basement in the light of facts and regional tectonic context (in Slovak with English summary). Mineralia Slovaca, 27: 1-8.

Soták, J., Biroň, A., Prokešová, R., Spišiak, J., 2000. Detachment control of core complex exhumation and back-arc extension in the East Slovakian Basin. Slovak Geological Magazine, 6: $130-132$

Soták, J., Biroň, A., Dunkl, I., Lebedev, V., Magyar, J., Prokešová, R., 2005. Syntéza poznatkov o iňačovskej jednotke litostratigrafické, metamorfné, geochronologické a štruktúrno-tektonické dáta (in Slovak with English summary). Mineralia Slovaca, 37: 209-213.

Spišiak, J., Pitoňák, P., Petro, M., 1988. Metaultramafity z oblasti Jasenie-Kyslá, Nízke Tatry (in Slovak with English summary). Mineralia Slovaca, 20: 143-148.

Spišiak, J., Hovorka, D., Pitoňák, P., 1998. Báziká a ultrabáziká v d'umbierskej zóne Nízkych Tatier - petrologické a metalogenetické aspekty (in Slovak with English summary). Mineralia Slovaca, 30: 15-22.

Spišiak, J., Soták, J., Magyar, J., Rojkovič, I., 2000. Ultrabasites from the East Slovakian basin basement (in Slovak with English summary). Mineralia Slovaca, 32: 305-306.

Spišiak, J., Soták, J., Biroň, A., Mikuš, T., 2001. Cr-spinels from serpentinitic sandstone of the Šambron Zone (Eastern Slovakia) (in Slovak with English summary). Mineralia Slovaca, 33: 499-504.

Stankovič, J., Ivan, P., Andráš, P., 2001. Accessory chromian spinels in heavy fraction of stream sediments at Jasenie in Nízke Tatry Mts. (in Slovak with English abstract). Mineralia Slovaca, 33: 505-508.

Starobová, M., 1962. Těžké minerály východoslovenského magurského flyše a vnitřního bradlového pásma (in Czech). Geologické Práce, Zošit, 63: 47-52.

Stern, G., Wagreich, M., 2013. Provenance of the Upper Cretaceous to Eocene Gosau Group around and beneath the Wienna Basin (Austria and Slovakia). Swiss Journal of Geosciences, 106: 505-527.

Stevens, R.E., 1944. Composition of some chromites of the Western Hemisphere. American Mineralogist, 29: 1-34.

Stormer, J.C., 1972. Mineralogy and petrology ofthe Raton-Clayton volcanic field, northeastern New Mexico. GSA Bulletin, 83: 3299-3322.

Stránik, Z., 1965. Geology of the Magura Flysch of the Čergov Mts. and western part of the Ondavská vrchovina hills (in Czech). Sborník Geologických Vied, Západné Karpaty, 3: 125-173.

Stupka, O., Bondar, R., Poberezhskyy, A., 2011. Geochemical peculiarities of basalts of the Trostyanets volcanogenic complex (Ukrainian Carpathians). Biuletyn Państwowego Instytutu Geologicznego, 444: 187-190. 
Su, B.X., Zhang, H.F., Sakyi, P.A., Yang, Y.H., Ying, J.F., Tang, Y.J., Ma, Y.G., 2011. The origin of spongy texture in minerals of mantle xenoliths from the Western Qinling, central China. Contributions to Mineralogy and Petrology, 161: 465-482.

Varishchev, A., 1997. Major and trace element geochemistry of Mesozoic igneous formation of the Ukrainian Carpathians as an indicator of paleotectonic settings. Przegląd Geologiczny, 45: 1109-1110.

Wessa, P., 2016. Free Statistics Software, Office for Research Development and Education, version 1.1.23-r7, URL http://www.wersa.net/[cit. 13. 03. 2016]

Wieser, T., 1952. The ophiolite from Osielec (in Polish with English summary). Annales Societatis Geologorum Poloniae, 21: 319-327.

Winkler, W., Ślączka, A., 1992. Sediment dispersal and provenance in the Silesian, Dukla and Magura flysch nappes (Outer Carpathians, Poland). Geologische Rundschau, 81: 371-382.

Winkler, W., Ślączka, A., 1994. A Late Cretaceous to Paleogene geodynamical model for the Western Carpathians in Poland. Geologica Carpathica, 45: 71-82.
Žec, B., Kaličiak, M., Konečný, V., Lexa, J., Jacko, S. jr., Baňacký, V., Karoli, S., Potfaj, M., Rakús, M., Petro, L'., Spišák, Z., Bodnár, J., Jetel, J., Boorová, D., Zlinská, A., 1997. Explanations to the geological map of the Vihorlatské and Humenské vrchy Mts. (1:50,000) (in Slovak with English summary). Publ. D. Štúr - Geological Survey of Slovak Republic, Bratislava.

Žec, B., Gazdačko, L., Kováčik, M., Kobulský, J., Bóna, J., Pristaš, J., Potfaj, M., 2006. Geological map of the Nízke Beskydy Mts. - central part $(1: 50,000)$. Publ. Ministry of the Environment of the Slovak Republic and State Geological Institute of Dionýz Štúr, Bratislava.

Žec, B., Gazdačko, L., Kováčik, M., Kobulský, J., Bóna, J., Potfaj M., Pristaš, J., Žecová, K., Derco, J., Kucharič, L'., Marcin, D., Petro, L'., Zlinská, A., Siráňová, Z., Vaněková, H., Buček, S., Konečný, P., 2011. Explanations to Geological map of the Nízke Beskydy Mts. - central part $(1: 50,000)$ (in Slovak with English summary). Publ. Ministry of the Environment of the Slovak Republic and State Geological Institute of Dionýz Štúr, Bratislava. 